\title{
Detrital Zircon Provenance of Upper Cambrian-Permian Strata and Tectonic Evolution of the Ellsworth Mountains, West Antarctica
}

John P. Craddock, Geology Dept., Macalester College, St. Paul, MN 55105 USA

Paul Fitzgerald, Geology Dept., Syracuse University, Rochester, NY

Alex Konstantinou, Cyprus Hydrocarbons Company, Nicosia, Cyprus

Alex Nereson, Earth and Planetary Sciences Department, University of California-Santa Cruz, 1156 High Street, Santa Cruz, CA

Robert J.J. Thomas, Council for Geoscience, 3 Oos Street, Bellville, 7535 South Africa

\begin{abstract}
Detrital zircons from the upper Cambrian-Devonian sandstones (Crashsite Group; $\mathrm{n}=485$ ) and Carboniferous tillite (Whiteout Conglomerate; $\mathrm{n}=81$ ) of the Ellsworth Mountains, Antarctica record a steady supply of Neoproterozoic (“Pan-African") orogeny ( 550-600 Ma), Grenville ( 1000 Ma) and Neoarchean ( 3000-3500 Ma) zircons into the northern marginal basin of Gondwana. The overlying Permian Glossopteris-bearing Polarstar Formation shales $(\mathrm{n}=85)$ have the same zircon provenance as underlying units but also include a dominance of depositional-age (263 Ma) euhedral zircons which are interpreted to be of local, volcanic arc origin. Modeling of detrital zircon provenance suggests that source areas were present in Pan-African and Laurentian crust throughout the Paleozoic. We also report calcite twinning strain results (12 strain analyses; $\mathrm{n}=398$ twins) for the Cambrian Minaret Fm. in the Heritage range which is predominantly a layer-parallel shortening strain in the direction (WSW-ENE) of Permian Gondwanide orogen thrust transport. There is a secondary, sub-vertical twinning strain overprint. The initiation of localized lower-middle Cambrian
\end{abstract}


rifting (Heritage Group deposition) in Grenville-aged crust as Gondwana amalgamated and the subsequent Jurassic counterclockwise rotation of the Ellsworth-Whitmore terrane out of the Permian Gondwanide belt into central Antarctica each remain tectonic curiosities.

\section{Introduction}

The Ellsworth Mountains lie in the interior of West Antarctica, are 350 by $80 \mathrm{~km}$ in dimension, and are structurally perpendicular to adjacent crustal fragments (Fig. 1). They are divided into the northern Sentinel range and the lower, southern Heritage range. The Ellsworth Mountains are the highest standing feature in Antarctica with the Vinson Massif reaching $4892 \mathrm{~m}$. These mountains are part of the Ellsworth-Whitmore terrane (EWT; 720,000 km²), which are tectonically isolated from the reminder of the continent (Anderson et al. 1962; Craddock, 1966, 1972; Schopf, 1969; Dalziel and Elliot, 1982; Maslanyi and Storey, 1990; Curtis and Storey, 1996; Figure 1). The EWT is located in central Antarctica and is composed of Grenville-aged crust (Pankhurst and Millar, 1987; Flowerdew et al. 2007; Craddock et al. 2008; 2016) and was the site, on the southern margin of Gondwana, for deposition of 13,000 m of conformable Cambrian-Permian sediments including the classic Gondwana sequence: upper Cambrian-Devonian sands (Crashsite Group), Carboniferous tillites (Whiteout Conglomerate) and Permian near-shore, fossiliferous shales (Polarstar Formation; Webers et a. 1992). The lower half of this stratigraphic sequence $(\sim 7000 \mathrm{~m})$ is the middle-upper Cambrian Heritage Group which is a volcaniclastic sequence deposited unconformably on rifted Grenville-aged crust that was both in-board of the convergent Gondwana margin and unaffected by the proximal Ordovician Ross orogeny (Curtis and Lomas, 1998; Curtis et al. 1999a, b; Figures 2 and 3). There is 
now detrital zircon data for the upper Cambrian-Permian part of the Ellsworth Mountains section and no strain data.

One goal of this study was to use detrital zircon populations in the Ellsworth Mountains stratigraphic section to better resolve the location of the EWT during Paleozoic sedimentation, by comparing the detrital zircon age spectra obtained with the known ages of possible surrounding crustal blocks in Gondwana. In addition, we seek to better constrain the location of the EWT Grenville crust as part of diverging Rodinia (Moores, 1991; Dalziel, 1991, 1992, 1997; Goodge et al., 2008, 2010, 2012) as Cambrian sedimentation commenced. We report $\mathrm{U} / \mathrm{Pb}$ detrital zircon results from the Cambro-Devonian Crashsite Group (northern Heritage Range and Vinson Massif profile; 6 samples), the Carboniferous Whiteout Conglomerate (tillite; 1 sample) and the Permian Polarstar Formation (1 sample; see Elliot et al. 2016) and compare these results with Flowerdew et al. (2007; 2 samples, upper Heritage Group; 1 sample of the upper Crashsite Group) for the Ellsworth stratigraphic section as part of the Grenville-cored southern margin of Gondwana. We also report calcite twinning strain results from the Cambrian Minaret Fm. in the Heritage Range and discuss these results relative to the Gondwanide orogeny in the EWT.

\section{Geologic Setting}

Tectonically, the Ellsworth Mountains are situated between the East Antarctic craton and the accreted terranes of West Antarctica, namely the Antarctic Peninsula, Thurston Island and Marie Byrd Land (Dalziel and Elliot, 1982; Dalziel et al. 1987; Curtis and Storey, 1996). The Cape Fold Belt of Africa (DuToit, 1937; Halbich, 1982), 
the Sierra de la Ventana Mountains in Argentina (Von Gosen et al. 1987; Cobbold et al. 1991), the Falkland archipelago and the Ellsworth Mountains (Craddock, 1983; Webers et al. 1992) were all segments of one late Proterozoic-Paleozoic margin deformed in the early Permo-Triassic Gondwanide orogen (De Wit and Ransome, 1992). The preferred Gondwanide location of the EWT is $\sim 90^{\circ}$ clockwise from its present location (Watts and Brammall, 1981; Randall and Mac Niocaill, 2004; Cambrian paleopole solutions) in proximity to the Pensacola Mountains and the Argentina Range that lie in the Weddell Sea sector of the Transantarctic Mountains, a location that aligns all structural elements (Curtis, 1997, 1998, 2001). When the EWT diverged from Gondwana, the process included a bimodal igneous suite including pervasive Jurassic mafic intrusions (e.g., Dufek massif; 180 Ma; Minor and Mukasa, 1997) and extrusives (e.g., the Ferrar dolerite; 182.779 + / - 0.033 Ma; Burgess et al. 2014) as part of the Tasman-Karoo LIP (Craddock, 1972; Storey et al., 1988; Kyle, 2000; Craddock et al., 2008; 2016). These Jurassic mafic rocks are slightly older than the intrusion ages of granites in the EWT (173-177 Ma; Craddock, 1972; Storey et al. 1988; Craddock et al. 2016). Thus, granitic intrusion occurred after rotation of the EWT into its final position relative to the Weddell Sea (Grunow et al. 1987; Grunow, 1993; Elliot and Fleming, 2000). It remains unclear how and when the EWT moved to its current location in central Antarctica as Mesozoic and Cenozoic basin fill in the evolving, adjacent Weddell Sea is apparently undeformed (Huebscher et al. 1996; Grunow, 1993). Subsequent uplift of the EWT, as documented by the fission track study by Fitzgerald and Stump (1991) using the Devonian Crashsite Quartzite profile in the Sentinel Range, documents $4 \mathrm{~km}$ of Cretaceous (100 Ma) exhumation which led Dalziel (2008) to propose that the Ellsworth Mountains have long been a central glacial buttress (total relief $=7 \mathrm{~km}$ ) thereby stabilizing Tertiary ice volumes in East and West Antarctica. POLENET is a 
multi-national consortium undertaking a continent-wide GPS and seismic array to document active tectonism across Antarctica (Dalziel, 2008).

The Ellsworth Mountains are comprised dominantly of a 13,000 $\mathrm{m}$ basal middle Cambrian to Permian apparently conformable sedimentary sequence (Webers et al. 1992; Curtis and Lomas, 1999; Curtis et al. 1999a, b; Fig. 3). It contains two groups, the Heritage (Lower Cambrian to Upper Cambrian; marbles, argillites, quartzites, conglomerates with some volcanics) and the Crashsite Groups (Upper Cambrian to Devonian, dominantly quartzites). Other fossiliferous sections such as the middle Cambrian Springer Peak coquina (70 new species; Webers et al. 1992) as well as a variety of dated igneous intrusions and igneous clasts better refine the stratigraphic column (Flowerdew et al. 2007; Figure 3). Clastic, carbonate and volcaniclastic sediment of presumed Cambrian age are known in widely separated locales around the EWT and likely correlate with the Heritage section and thereby bear on the early Cambrian rifting of the EWT (Storey and MacDonald, 1987). The Heritage and Crashsite Groups are separated by a series of transitional beds (Webers et al. 1992; Curtis, 2001) that had been interpreted as subtle evidence for the Cambro-Ordovician Ross orogeny in the EWT (Goldstrand et al., 1994; Rees et al., 1995; Rees and Duebendorfer, 1996). However, these transitional beds are interpreted by later workers as local unconformities without regional significance notably as there is structural continuity across this boundary, and thus the Ross Orogeny, which is so prelevant in the Transantarctic Mountains (e.g., Stump, 1992), is concluded to be absent in the Ellsworth Mountains by Curtis (2001). Two younger formations, the Permo-Carboniferous Whiteout Conglomerate (marine and terrestrial tillites) 
and the Permian Polarstar Formation (argillite and sandstone) complete the upper section. Craddock et al. (1965) first described Glossopteris flora in the Polarstar Formation at the top of the Ellsworth stratigraphic section thereby connecting these mountains to the Gondwana (Karoo) basin and Gondwanide orogeny (Schopf, 1969; Craddock, 1977).

The Ellsworth Mountains are a NNW-plunging anticlinorium exposing Cambrian sediments and metavolcanics in the southeast and the Permian Polarstar Formation in the northwest as part of the Gondwanide orogen thrust belt (Craddock, 1977; Figure 2). Thrusts dip to the WSW and hangingwall motions are up and to the ENE (Sporli et al. 1992; Craddock et al. 1992; Curtis, 2001) and a layer-parallel shortening strain is present in the Cambrian Minaret carbonates (Craddock et al. 1997). Folds are overturned to the ENE and an axial planar cleavage is present; foliation-bound kinematics also indicate top-to-theENE motion (Curtis, 1997, 1998, 2001) in rocks that reached greenschist facies metamorphic grade (Bauer, 1992). The Cambrian Minaret Formation carbonates host a 3-phase carbonate breccia body formation that was contemporaneous with the Gondwanide orogen and is seemingly unique to this thrust belt (Sporli et al. 1992; Craddock et al. 2008). Post-Gondwanide dextral deformation, parallel to the overall strike, is also reported (e.g., Dolence fault; Craddock, 1980; Craddock et al. 1986; Curtis, 2001), perhaps related to Mesozoic rotation and subsequent translation of the Ellsworth-Whitmore terrane.

\section{Ellsworth Mountains Stratigraphy}

The Heritage Group 
The southern Heritage Range is composed of $\sim 7000 \mathrm{~m}$ of heterogeneous clastic, volcaniclastic and fossiliferous carbonate sediments of the Cambrian Heritage Group. Some parts of the Heritage Group are fault-bounded and the stratigraphy is locally discontinuous and with local unconformable surfaces (Webers et al. 1992; Curtis et al. 1999; Curtis, 2001). Radiometric ages and detrital zircon spectra within the Cambrian section by Flowerdew et al. (2007) have refined the stratigraphic column initially proposed by Craddock (1969; Figure 3).

\section{Minaret Formation}

The Minaret Fm. is a shallow marine deposit of upper Cambrian age. The unit is 600-900 m thick and is dominantly a carbonate with oolites, oncolites, flatpebble conglomerates, ripples and cross beds. Upper Cambrian fossils are numerous and the Minaret Fm. was deposited on the Frazier Ridge-Springer Peak- Liberty Hills Fm. (Fig. 3; Buggisch and Webers, 1992; Buggisch et al. 1992). The Minaret Fm. provides a beautiful carbonate for calcite strain analysis (Methods in Appendix 1) and is the carbonate host for the synorogenic monomineralic 3-phase calcite breccia bodies (Sporli et al. 1992; Craddock et al. 2008). The Heritage (see above)-Minaret section correlate with the GamtoosKango inliers in southern Africa (Miller et al. 2016).

\section{Crashsite Group}

The overlying Crashsite Group is $~ 3000 \mathrm{~m}$ in thickness and the base may be Cambrian, Silurian or Ordovician but appears to be conformable with the late Cambrian underlying Heritage Group (Sporli, 1992; "transition beds" of Curtis, 2001). Paleocurrent and index fossil data are sparse in these shallow marine 
sands and rare, interbedded shales and conglomeratic layers. The relief of the Sentinel Range (4892 m) is the result of the enormous thickness of resistant Crashsite quartzites that are folded, overturned and repeated (Craddock et al. 1992). Crashsite Group quartzites are common in the Heritage Range and, since the entire Ellsworth Mountains are north-plunging, correlations with the overlying Crashsite Group quartzites in the high-standing Sentinel Range have proven challenging (Fig. 5). The Crashsite Group correlates with the WittebergBokkeveld and Table Mtn. Fms. in the Cape Mountains, the Ventana and Curamalal Fms. in the Ventana Mountains, and the Port Stanley-Fox Bay-Port Stephens Fms. in the Falkland Islands.

\author{
Whiteout Conglomerate \\ Exposures of the Whiteout Conglomerate in the Ellsworth Mountains \\ include the massive, folded diamictite in the northern Sentinel Range and the \\ thinly-bedded, interbedded diamictite-tillite in the southern Meyers Hills of the \\ Heritage Range (Matsch and Ojakangas, 1992). Exposures in the Meyers Hills \\ included mixed diamictite-tillite zones with boulder pavements (the grounding \\ line) and abundant glacially striated clasts all indicating the ice flowed from the \\ southern Meyers Hills toward the northerly open ocean (Sentinel Range) in the \\ Carboniferous. The Whiteout Conglomerate correlates with the Dwyka Fm. in S. \\ Africa, the Sauce Grande Fm. in Argentina and the Fitzroy Fm. in the Falkland \\ Islands.
}

Polarstar Formation 
Craddock et al. (1965) first described Polarstar Formation Glossopteris flora in central Antarctica from the top of the Ellsworth stratigraphic section thereby connecting these mountains to the Gondwana basin and Gondwanide orogeny (Schopf, 1969; Craddock, 1977). The Polarstar Formation is $>1000 \mathrm{~m}$ and composed of a lower argillite, sandy argillite and upper coal measures with paleocurrents $(n=119)$ that dominantly flowed toward the northwest, away from Gondwana (Collinson et al. 1992). The Polarstar is weakly metamorphosed but intensely folded (Castle and Craddock, 1975) and our sample is from the lower argillite unit collected near Polarstar Peak. Elliot et al. (2014) have recently reported detrital zircon and zircon ash crystallization results for the Polarstar Formation and equivalent units nearby. The Polarstar Fm. correlates with the marine Ecca and terrestrial Beaufort Group in the Cape-Karoo system, the Pilahuinco Fm. in the Ventana Mountains and the Black Rock Slates in the Falkland Islands.

\section{Sampling and Results}

We report here the details of the analysis of detrital zircon populations for eight samples from the northern Heritage Range to the northern end of the Sentinel Range in the Ellsworth Mountains (Figures 1, 2 and 3; U-Pb methods in Appendix 1). Webers et al. (1992) provides a compendium about the Ellsworth Mountains, including the exploration history in the Preface, and a geologic map (Craddock et al. 1986) that is simplified in Fig. 2. A stratigraphic column, after Webers et al. (1992) and Flowerdew et al. (2007) is found in Figure 3. Detrital zircon relative probability results, including three samples from Flowerdew et al. (2007), are presented in Figure 4, and the U-Pb age data are summarized in Table 
1 and reported in full in Appendix 2. Calcite strain sample sites are located on Fig. 2, stereoplots in Fig. 5, and data are presented in Table 2. Field structural relations are presented in Figures 6-8.

\section{Detrital Zircon Spectra}

Crashsite Group Quartzites

Seven samples were collected, three from the northern Heritage Range (HR-6, HR-37 and HBJ) and four from a traverse up the Vinson Massif (HBO, HAS, HAT, HBD; Table 1). All but sample HBO had robust zircon yields (Appendix 2) and the $\mathrm{U}-\mathrm{Pb}$ age results are presented in Figure 4. All six results $(\mathrm{n}=485$, plus $91 \mathrm{U}-\mathrm{Pb}$ ages from Flowerdew et al. 2007) are fairly consistent with spectral peaks at 550-600 and 1100 Ma with small numbers of older zircons. The youngest zircons are 486, 504, 505, 511, 484 and 484, from bottom to top, are Cambro-Ordovician ages which do not better constrain a Crashsite depositional age. We also dated eleven grains between 3000 and 3452 Ma.

\section{Whiteout Conglomerate}

Matsch and Ojakangas (1992) report that the $1000 \mathrm{~m}$ thick Whiteout is populated by quartzite $(66 \%)$ and granite clasts $(17 \%)$ and petrographic analysis reveals a variety of feldspars and garnet. Samples from both the northern Sentinel Range and Meyers Hills have significant pyrope garnets in their heavy mineral splits as does the Fitzroy Formation in the Falkland Islands and the Dwyka Formation in southern Africa (Craddock et al. 2008). The detrital zircons $(\mathrm{n}=81)$ from the northern Sentinel Range Whiteout Conglomerate include a primary $\mathrm{U}-\mathrm{Pb}$ age population at $550 \mathrm{Ma}$ and a few lesser peaks at 1100, 1800 and 
$2700 \mathrm{Ma}$ (Fig. 4). The youngest zircon age is $519 \mathrm{Ma}$. The oldest zircon age is 3569 Ma.

\section{Polarstar Formation}

Zircon grains from the Polarstar Formation exhibit two morphological populations. About half of the zircon crystals are euhedral and unabraded (Fig. 4) and the other half of the zircon crystals are usually rounded, abraded zircons (Fig. 1, n=43). The euhedral zircons are all young and are presumed to be ashfall zircons from a proximal magmatic event; possibly arc-related magmatism ( $\mathrm{n}=42$; see Fildani et al. 2010 and McKay et al. 2015 for a correlation to Permian Karoo sediment ash fall zircons). A weighted mean age of the young zircons was calculated and interpreted to reflect a depositional age of $263.4 \pm 1.4 \mathrm{Ma}(95 \%$ confidence level; MSWD of 1.6; Fig. 4 inset). This depositional age is consistent with the results of Elliot et al. (2014) who report maximum depositional ages of 270 and $260 \mathrm{Ma}$, respectively as well as the crystallization ages of interbedded ash deposits (258 and $262 \mathrm{Ma}$ ). The rounded zircons give age distributions with peaks at 550, 800 and $1200 \mathrm{Ma}$ (Fig. 4); the oldest zircon is $3163 \mathrm{Ma}$. The U-Pb zircon analyses that are older than Permian yield a similar distribution (age populations and peaks) to the older part of the section (Crashsite Group).

\section{Structural Geology \& Calcite Twinning Strains}

Folds in the southern Heritage Range are periclinal and fold hinges dip to the WSW (verge to the ENE) and generally contain an axial planar cleavage. The Minaret Fm. limestones are marbles in places and can be mylonitic with top-to- 
the-NE porphyroclasts and porphyoblasts (Fig. 6; Curtis, 1997, 2001). Strike-slip faults also crosscut the Gondwanide folds and these fault planes (Fig. 6) are occasionally filled with calcite breccia material. The breccia bodies had a threestage genesis, with the older breccias containing cleaved upper Cambrian Minaret limestone clasts supported by calcite, whereas the younger breccias are nearly clast-free and composed entirely of matrix calcite (Fig. 7). Breccia clasts, calcite matrix and detrital matrix samples are entirely composed of calcite and stable isotopes $(\mathrm{C}, \mathrm{O})$ and fluid inclusions $\left(140^{\circ} \mathrm{C}\right.$ homogenization temperature $)$ suggest that the breccias formed as part of a closed geochemical system within the Minaret Fm. at considerable depth ( 5000 m; Craddock et al. 2008). Breccia bodies are offset by Gondwanide orogen thrusts (Fig. 8a) and are therefore synorogenic features; mechanical twins are present in breccia body matrix calcite but no oriented samples were collected. Breccia bodies are sheared (reverse and sinistral motion) along the post-Gondwanide Dolence fault (Figs. 2, 8b) that is parallel to the structural fabric of the Ellsworth Mountains.

The deformation of the Marble, Independence and Patriot Hills in the southern Heritage Range is consistent with Gondwanide orogen deformation throughout the Ellsworth Mountains (Sporli and Craddock, 1992a,b). Eight oriented carbonate samples were collected in 1979-80, which resulted in 12 calcite twinning strain results (Table 2, Fig. 5). Strain results for 6 limestones record a layer-parallel shortening strain in the direction of inferred Gondwanide thrust transport, or normal to fold axes (WSW-ENE). Two vertical calcite veins record horizontal shortening parallel to the Gondwanide thrust transport direction. Strain overprints (high NEV \%) are evident in 3 limestones and 1 vein, and in each case a sub-vertical shortening strain was imposed on the layer-parallel 
fabric. Differential stresses responsible for twinning and the resultant strain magnitudes are consistent with other thin-skinned thrust belts (Table 2).

\section{Discussion}

Depositional History and Provenance

The Ellsworth Mountains stratigraphic section is unique as nearly half of the conformable 13,000 m section is composed of heterogeneous clastic and volcaniclastic Cambrian sediments and local intrusions that rest on Grenville basement and were deposited as the margin rifted in the Cambrian (Curtis, 1999). The EllsworthWhitmore terrane avoided the regional Pan African orogeny (550-600 Ma) and Cambro-Ordovician deposition was unaffected by the proximal Ordovician Ross orogeny ( 530-500 Ma; Paulsen et al. 2007). Gondwana reconstructions (Watts and Brammall, 1981; Grunow et al., 1987; Lawver et al. 1991; Randall and Mac Niocaill, 2004) locate the Ellsworth-Whitmore terrane in the Natal embayment adjacent to S. Africa, the Falkland Islands, the Coats Land terrane, and along the Transantarctic Mountains near the Grenville crust in the Grunehogna terrane (Jacobs et al. 2003 a,b; Loewy et al. 2011) thereby discarding the equatorial location of the EWT in the Cambrian (Randall et al. 2000). Cambrian sedimentation and rift-related volcanics are also preserved along the Gondwana margin in southern Africa (Kango, Kaaimans and Gomtoos inliers; Miller et al. 2016), with local unconformable surfaces, before the onset of late Cambrian shallow marine sandstone deposition (Curtis, 1999a). Cambrian mafic dikes in the Falkland Islands indicate contemporaneous crustal extension (Curtis et al. 1999b). Storey and MacDonald (1987) report 100 m of flat-lying volcaniclastic sediments in the southern EWT near the north side of the Thiel Mountains, $\sim 400 \mathrm{~m}$ of vertical carbonates in the Nash Hills, and $\sim 120 \mathrm{~m}$ of flat-lying red sandstones at Mt. 
Johns (Figure 1). These are all presumed to be Cambrian in age and may correlate with the Heritage Group. What was adjacent to the southern margin of Gondwana at the end of the Proterozoic that rifted away and commenced Cambrian sedimentation on Grenville crust?

Paleocurrents are not common in the Cambrian Heritage Group sediments in the Ellsworth sequence and perhaps this is expected for volcaniclastic sediments in a narrow $(\sim 100 \times 500 \mathrm{~km})$ rift basin. The overlying Gondwana sequence is generally a shallow marine sequence and the Cambro-Devonian sandstones (Tankard and Barwis, 1983; Hiller and Taylor, 1992) with poorly organized sediment transport (Sporli et al. 1992) and intensely folded (i.e., nappes) making interpretations difficult. Carboniferous tillites preserve welldefined ice flow indicators from central Africa and Antarctica (Visser, 1987; Matsch and Ojakangas, 1992). Permian Glossopteris-bearing Polarstar Formation (Curtis and Hyam, 1998; Collinson et al. 1992) and equivalent units in the Karoo basin preserve a mix of paleocurrent data (Cole et al. 1998; Andersson et al. 2006). The Frasier Ridge-Crashsite Group detrital zircons all record a steady stream of Pan African (550-600 Ma) and Grenville ( 1100 Ma) aged zircons into the Gondwana basin. The Whiteout Conglomerate (tillite) has the same detrital zircon age spectra with small age peaks at $\sim 2000, \sim 2800$ and $\sim 3600 \mathrm{Ma}$, similar to the detrital zircon age spectra in the Fitzroy, Dwyka and Sauce Grande tillites (Craddock, 2011). The Whiteout, Fitzroy, Dwyka and Sauce Grande Fm. tillites also contain healthy populations of pyrope garnets (Craddock et al. 2008; Craddock and Thomas, 2010). The Polarstar Formation is dominated by arcrelated Permian ashfall zircons (263 Ma; Fig. 4; see Millar et al. 2001, 2002; Fildani 
et al. 2010; Elliot et al. 2014; McKay et al. 2015) and a smaller population of Pan African and Grenville detrital zircons. Only the youngest zircons in the lower Fraser Ridge Formation (518 Ma) and upper Wyatt Earp Member (375 Ma) of the Crashsite Group better constrain the depositional ages of these units and are consistent with the overall stratigraphic sequence. The consistency of youngest zircon ages in the majority of the Crashsite Group samples may reflect sample duplicity in a complexly folded and repeated section (Fig. 9).

Deposition on the southern margin of Gondwana started with local infilling of the Cambrian rift basin (e.g., Heritage Group) followed conformably by the rest of the Gondwana sequence. As the entire sedimentary sequence is conformable and largely marine, recycling of zircons was unlikely. The deposition of the Paleozoic section in the Ellsworth Mountains on Grenville crust and in proximity of southern Africa predictably yields both Grenvillian and Pan African zircons (Fig. 4). Paleocurrent studies also support a sediment source from Gondwana toward the basin including the ultramafic pyrope garnets found in the Carboniferous tillites. Flowerdew et al. (2007) used detrital zircon U-Pb geochronology and Hf-isotopic compositions (a mixture of positive and negative values) to propose four zircon source areas that are not necessarily in agreement with paleocurrent indicators. In this study, we have chosen a different approach (see Konstantinou et al. 2014) using a ternary plot of detrital zircon ages for the entire sample suite $(n=775)$. In this plot we portray the three geologically related age groups of 550-600 Ma (Pan African group), 950-1350 Ma (Grenville-age zircons) and a combined mode of 1450-2000 Ma plus 2500-3800 Ma, representing Laurentian (or Rodinian?) cratonic terranes. As mentioned earlier, few zircons 
were observed in the age range of 2000-2500 Ma which is a well-known period of quiescence of zircon production in Laurentia. The proportions of the three zircon age modes were calculated for each sample, together with an estimate of the standard error for each mode's proportion. These proportions were plotted on a ternary diagram illustrating the relative zircon age proportions of the three groups outlined above. For all of the samples (except the Polarstar Formation sample; see earlier discussion), $>75 \%$ of the zircon data is represented on the ternary diagram. This plot helps us outline potential sources for the detrital zircons in the EWT samples. The most straight-forward interpretation of these detrital zircon signatures is that the zircons were primarily sourced from a combination of Pan African and Laurentian crustal sources that contained the three age groups described above but lacked a 2000-2500 Ma crystalline source (Figure 10). Detrital zircon studies of younger, adjacent terranes, the Antarctic Peninsula, Patagonia and Zealandia, have very different detrital zircon age spectra, as expected (Barbeau et al. 2009).

Our data suite has 15 zircon ages that are Paleo-Mesoarchean (2800-3600 Ma; Table 2). The age distribution is as follows: Crashsite Group (2811, 3141, 3211, 3452 Ma [Mt. Twiss Member]; 2976, 2981, 3002, 3018, 3158 Ma [Landmark Peak Formation]; 2964, 2968, 3024 Ma [Mt. Liptak Formation]; 2893 Ma [Mt. Wyatt Earp Formation], Whiteout Conglomerate (3569 Ma), and Polarstar Formation $(3163 \mathrm{Ma})$. Hf isotope data exists for $2893(\varepsilon \mathrm{Hf}=-4.4)$ and $3141(\varepsilon \mathrm{Hf}=-$ 0.9) Ma grains in the Crashsite Group (Flowerdew et al. (2007), and perhaps these are Laurenitan zircons. Harley and Kelly (2007) have compiled the 
complexity of exposed Archean crust in Antarctica (ages of 2460-4000 Ma), data supported by studies of modern Antarctic glacial tills that source Archean crust under the modern ice sheet (Goodge et al. 2008). In both cases, the PaleoMesoarchean detrital zircons in the Ellsworth Paleozoic section (no eHf data) could have been derived from the Nimrod Group in the Transantarctic Mountains or from central Antarctic crustal sources (Boger, 2011; Veevers and Saeed, 2011) although this is not supported by limited paleocurrent data. PaleoMesoarchean zircons are known in the Minnesota River valley (MRV) of the Superior province of southern Laurentia (no عHf data; Bickford et al. 2006; Schmitz et al. 2006) and could have been a primary or recycled source area (no عHf data; Craddock et al. 2013). Antarctica was covered by a polar ice cap for 65 Ma (Lopez-Gamundi, O.R., and Buatois, L.A., 2010) in the Carboniferous which likely limited much sediment delivery from central Antarctica to this part of the Gondwana basin.

Goodge et al. (2010) have argued convincingly that East Antarctica and Laurentia were sutured together during intrusion of anorogenic granites ( 1.45 $\mathrm{Ga}$ ) in both continents thereby supporting the tectonic ("SWEAT") hypothesis of Moores (1991) and Dalziel (1991, 1992, 1997). Much of Rodinia remained sutured together by the central Pan African orogeny (600-550 Ma) as a precursor to the amalgamation of Gondwana (Torsvik et al. 2008). The Grenville crust of the EWT fits nicely in the Grenville-Mozambique belt in these end-Proterozoic reconstructions but was then rifted in the middle Cambrian in a back-arc setting (Figure 6; Curtis et al. 1999a; Curtis, 2001) before the onset of upper Cambrian- 
Permian shallow marine sedimentation. Dalziel (1997) shows the reconstruction of Rodinia with a continental block containing the EWT as a key element in these reconstructions linked with Laurentia. The paleomagnetic fit for SWEAT is not perfect (Torsvick et al. 1996; Van Staal et al. 1998; Curtis, 2001) and the rifting event at $550 \mathrm{Ma}$ is earlier than Heritage Group deposition although there are significant paleobiologic connections between Laurentian and Ellsworth middle Cambrian trilobites (Jell, 1974; Jago and Webers, 1992) and conodonts (Webers et al. 1992). The ancestral mollusc, Monoplacophera, is only found at Taylors Falls, Minnesota (Laurentia) and in the middle Cambrian of the Ellsworth Mountains (Webers et al. 1992; Figure 7). Proterozoic rhyolites and granophyres (1.1 Ga) found in the Coats Land terrane also correlate with Keweenaw rift rocks in southern and central N. America (Loewy et al. 2011; Craddock et al. 2013). If the Coats Land terrane contains 1.0 Ga igneous rocks equivalent to the Keweenaw rift system in N. America (see Craddock et al. 2013) perhaps these rift-aged rocks intrude a fragment of Laurentian crust, an observation supported by the proximity of the EWT and Coats Land terranes and the Laurentian supply of detrital zircons we see in the Ellsworth section (Figures 4 and 11). A promixal zircon source is preferred to a model of across-plate fluvial transport (see Rainbird, 1992; Craddock et al. 2013), especially if the source area, Laurentia, is required to move to its N. America-Eur-Africa location at the start of the Taconic orogeny in the late Ordovician and was not part of Gondwana. Paulsen et al. (2016) report detrital zircon ages from Ross Supergroup deformed sandstones in the Wilson, Bowers and Roberston Bay terranes in the North Victorialand (NVL) area of the Transantarctic Mountains and their age spectra is very similar to the entire Ellsworth section: age peaks of Pan-African, Grenville and Paleo- 
Mesoarchean ages (3566 Ma is their oldest detrital zircon age).We cannot, however, rule out Archean east Antarctica as a source of these ancient zircons although the oldest groupings are 3100-3350 Ma (Veevers and Saeed, 2011) and our oldest detrital zircon in 3569 Ma.

\section{Deformational History}

The lower-middle Cambrian Heritage Group clastics and volcaniclastics were deposited on Grenville crust (Millar and Pankhurst, 1987; Craddock et al. 2016) in a localized extensional Ellsworth basin between cratonic east Antarctica, Africa, India, South America and Laurentia (Figs. 11 and 12) as Gondwana amalgamated. The Heritage Group is poorly studied (3 detrital zircon samples; Flowerdew et al. 2007) but the detrital zircon age spectra are consistent with a provenance with the rest of the younger Ellsworth section (Figs. 4) and the volcanic rocks are consistent with a localized rifting environment. The Heritage Group detrital zircon spectra (Pan African, Grenville and Meso-Archean age peaks) and rift-related volcanics also correlate with the Kango-KaaimanGomtoos Cambrian inliers in the Cape belt of the same age (Miller et al. 2016) although this extensional basin formation is separated from the Ellsworth Heritage extension (Fig. 11).

The Permian Gondwanide orogen produced a greenschist-grade penetrative deformation along the Gondwana margin where the Ellsworth Mountains were within the linear belt between the Cape-Falklands and Pensacola Mountains. The Minaret Fm. carbonates in the Heritage range provide an opportunity to unravel the deformation using twinned calcite which is not 
present up section (i.e., the Crashsite, Whiteout or Polarstar Fms.) or along the orogenic strike. The twinned calcite preserves a layer-parallel shortening strain that is parallel to the Gondwanide thrust transport direction and consistent with the fold, cleavage and kinematic observations across the Ellsworth Mountains (Craddock et al. 1992; Sporli and Craddock, 1992a,b; Curtis, 1997, 1998, 2001) and twinning strains reported from the upper Gondwana section in the Cape belt (Craddock et al. 2007). Both limestones and vein calcite record a sub-vertical shortening strain (4 samples; see shortening axis stereonet inset in Fig. 12) that is also observed in orogenic belts with stacked nappes (Craddock and McKiernan, 2007; Craddock et al. 2009). Breccia body formation, in 3 calcite stages, was contemporaneous with the peak Gondwanide orogen as cleaved Minaret Fm. limestone clasts are found in the breccias, vein calcite in the Minaret Fm. is often cleaved parallel to the range-wide penetrative cleavage, and breccia bodies are truncated by Gondwanaide orogeny thrusts (Fig. 8; Sporli et al. 1992; Craddock et al. 2008). Evidence of the Ordovician Ross orogen is not present. Breccia bodies are also truncated along the Dolence fault (Fig. 8) which has both reverse and sinistral kinematics and formed as a response to counterclockwise rotation of the Ellsworth-Whitmore terrane out of Gondwana in association with the intrusion of Jurassic granites into Grenville crust (Burgess et al. 2014; Craddock et al. 2016). Cretaceous uplift of $4 \mathrm{~km}$ (Fitzgerald and Stump, 1991) of the Sentinel Range is not well understood but the high elevation of the resistant Crashsite Group quartzites provided a buttress to ice motion in central Antarctica and stabilizes the ice cap. The tops of arêtes and horizontal glacial striations are at elevations of $\sim 3000 \mathrm{~m}$ indicating the recent loss of ice volume (Denton et al. 1992). 


\section{Conclusions}

The Ellsworth basin had a robust supply of Pan African, Grenville and Archean zircons from the late Cambrian to the Permian where, in the basal Permian Polarstar Formation, Gondwanide orogen volcanic arc eudedral zircons fell into the basin (263 Ma; 258 and 262 Ma from Elliot et al. 2014). Our detrital zircon results support the presence of a Laurentian zircon source which may have been Laurentia (i.e., N. America) in the Cambrian and, perhaps, Laurentian crust in Coats Land (or undiscovered, nearby in Antarctica). The tectonic mechanism for initiating the rifting that formed the Ellsworth basin (and Kango, Kaaiman and Gomtoos inliers), while surrounded in space and time by tectonic convergence, remains unclear (Figure 11). Resolution of this problem could be addressed by a thorough detrital zircon study of the Heritage Group and other presumed Cambrian sediments around the EWT (Storey and MacDonald, 1987). The Ellsworth Mountains experienced a penetrative deformation throughout the $13,000 \mathrm{~m}$ section that is consistent with other parts of the Permian Gondwanide orogen. Rare carbonates in the Gondwana section, namely the Cambrian Minaret Fm., preserve a layer-parallel shortening strain that is parallel to Gondwanide thrust transport but also record a sub-vertical shortening overprint. Vertical shortening is consistent with thrust stacking and large, overturned folds (Fig. 9) also seen in the Cape belt. Magmatism in the Ellsworth Mountains part of the Ellsworth-Whitmore terrane is absent (Craddock et al. 2016) and Jurassic counterclockwise terrane rotation may be preserved by the small-offset oblique faults like the Dolence fault (Fig. 8).

\section{Acknowledgements}


Craddock first visited central Antarctica in 1979-80 and would like to dedicate this effort to Jerry Webers (deceased 2008) as teacher, friend, mentor and colleague. Craddock also had the pleasure of working with Dick Ojakangas, Charlie Matsch (deceased 2014), Bernie Sporli, Ian Dalziel, Bob Rutford, George Denton, John Splettstoesser (deceased 2016) and Cam Craddock (deceased 2006) in the field. John Evans kindly supplied some of the images in Figure 9. The Laserchron crew at the University of Arizona was gracious, patient and awesome, as always. Konstantinou and Nereson were students at Macalester College and laser masters in Tucson. The Wallace Fund at Macalester College allowed Craddock to travel to the Gondwana 13 meeting in Dali, China to present these results. Bryan Storey gracefully contributed the basemap image in Figure 1. Paul Fitzgerald acknowledges support from National Science Foundation grants DPP 88-16655 and DPP 91-17441 that funded fieldwork in the Ellsworth Mountains. A review by John Splettstoesser is greatly appreciated.

\section{Figures}

Fig. 1: Sub-ice topographic DEM of Antarctica (A) with continental crust terranes identified (EANT: East Antarctic craton; AP: Antarctic Peninsula; TI: Thurston Island; MBL: Marie Byrd Land; EWM: Ellsworth-Whitmore Mountains; from Dalziel, 2008) and in (B), a detailed sub-ice DEM of central west Antarctica. Red-orange areas are exposed above ice whereas yellow areas are sub-ice and blue areas are below sea level. The Ellsworth Mountains are the highest peaks and were uplifted by a SW-dipping series of thrusts faults. Inset $C$ shows the relative position of the Ellsworth-Whitmore terrane in the Permian (Dalziel, 1997).

Fig. 2: A. Oblique aerial image of the Ellsworth Mountains looking north from the southern Heritage Range. Calcite strain sites are identified with stars (Fig. 5, Table 2). The Patriot Hills and Minaret Peak are identified in this image, and for reference in B, the shaded relief map of the Ellsworth Mountains, Antarctica showing the lower, southerly Heritage Range and the high peaks of the Sentinel Range. The Gondwanide thrust margin and transport direction is indicated (see Curtis, 1990). Detrital zircon samples sites are indicated (See Table 1, Figure 3). Samples 1,2 and 9 are from Flowerdew et al. (2007). A detailed geologic map of the range is found in Craddock et al. (1986).

Fig. 3: Stratigraphic column for the Ellsworth Mountains, Antarctica based on Webers et al. (1992) and Flowerdew et al. (2007). Radiometric ages are from Rees and Duebendorfer (1997), Rees et al. (1998) and Randall et al. (2000). Numbers in the column indicate detrital zircon samples from Figure 2 (see also Tables 1 and Appendix 2); samples 1, 2 and 9 are from Flowerdew et al. (2007). Calcite twinning strains are from the Minaret Pk. Fm. (Figure 5, Table 2).

Fig. 4: Summary relative probability plot for the Ellsworth Mountains, Antarctica including data from Flowerdew et al. (2007; open star symbol). Euhedral zircons (CL images above, with laser ablation holes) from the Polarstar Fm. produced a depositional age of 263 Ma. See Tables 1 and Appendix 2.

Fig. 5: Lower hemisphere projections of calcite twinning strain data (Table 2) for 
the Minaret Fm. limestones and veins. Turner (1953) compression axes are contoured. Strain axes: $\mathrm{e} 1=$ maximum shortening axis; $\mathrm{e} 2=$ intermediate axis; $\mathrm{e} 3=$ extension axis.

Fig. 6: Strike-slip faults cutting the Cambrian Minaret Fm., Heritage Range (A, B; mylonitic marble) with top-to-the-ENE kinematic indicators in Minaret mylonites (C) and Heritage Group volcaniclastics (D).

Fig. 7: (A) The "type" carbonate breccia body ( $~ 50 \mathrm{~m}$ high) in the southern Marble Hills of the Heritage Range. The vertical, cylindrical breccia body crosscuts an anticline-syncline pair and preserves a crude, sub-horizontal layering with clasts of cleaved Minaret Fm. marble. A second, horizontal breccia cylinder is present to the right. Breccia bodies crosscut each other (B) with younger breccias generally clast-poor and cleaved Minaret clasts are often serrated (C).

Fig. 8: (A) Carbonate breccia body hosted in Cambrian Minaret Fm. limestone truncated by a WSW-dipping thrust fault (top-to-the-northeast) and, (B) the Dolence fault (NW-SE strike) which juxtaposes folded Minaret Fm. limestones (that host breccia bodies) against Crashsite Group quartzites (see Fig. 2 for fault location). Sinistral motion kinematics are observed along the Dolence fault.

Fig. 9: Fold complexities in the Crashsite Group (Mt. Liptak and Landmark Peak Fms.) at high elevations in the Sentinel Range.

Fig. 10: Ternary diagram summarizing the detrital zircon data of the Elsworth Mts samples in terms of the three major geologically defined zircon age populations. The three apexes of the diagram represent a Pan-African zircon source end member (475-650 Ma), a Laurentian cratonal zircon source end member (1450-2000 Ma and 2500-3800 Ma) and a Grenville crust source end member (950-1350 Ma). The detrital zircon data of the samples in this study are normalized relative to these three age populations (projected on the ternary diagram) and define mixing assemblages between the Pan-African end member and an inferred Laurentian source that has approximately equal zircon-age proportions of Grenville crust and Laurentian craton. The error bars represent the statistical standard error of the proportions based on the sample size. For reference we plot the detrital zircon data from Cambro-Ordovician and Mesoproterozoic samples of the Laurentian Midcontinent region. The inset graph is a relative probability diagram of the Midcontinent Mesoproterozoic rift strata and Cambro-Ordovician arenites, illustrating the lack of zircon within the age range of $\sim 2000-2500 \mathrm{Ma}$.

Fig. 11: The northern margin of Rodinia representing the final divergence of Laurentia and the early Cambrian amalgamation of proto-Gondwana (see Dalziel, 1991, 1997; Curtis, 2001 and Loewy et al. 2001). Stippled areas are Granville crust, including the Ellsworth-Whitmore terrane, which is beginning to rift to accommodate deposition of $\sim 7000 \mathrm{~m}$ of middle-upper Cambrian volcaniclastic sediment (Webers et al. 1992; Curtis, 1999). 
Fig. 12: Schematic representation of the evolution of the Ellsworth-Whitmore terrane starting with rifting that led to the deposition of the Cambrian Heritage Group sediments, then the Cambrian-Permian Gondwana sedimentary sequence, all of which was deformed by the Gondwanide orogen. Intrusion of Jurassic granites followed as Gondwana diverged and the EWT rotated and uplifted to form the current high-standing mountain range.

\section{Tables}

Table 1: Detrital Zircon Sample Overview

Table 2: Calcite Twinning Strain Results

\section{Appendices \\ 1: U-Pb Dating and Calcite Twinning Strain Methods \\ 2: 8 DZ data tables (spreadsheet).}

Notes inserted below data Table 1:

1. 1. Analyses with $>10 \%$ uncertainty (1-sigma) in $206 \mathrm{~Pb} / 238 \mathrm{U}$ age are not included.

2. Analyses with $>10 \%$ uncertainty (1-sigma) in $206 \mathrm{~Pb} / 207 \mathrm{~Pb}$ age are not included, unless $206 \mathrm{~Pb} / 238 \mathrm{U}$ age is $<500 \mathrm{Ma}$.

3. Best age is determined from $206 \mathrm{~Pb} / 238 \mathrm{U}$ age for analyses with $206 \mathrm{~Pb} / 238 \mathrm{U}$ age $<900 \mathrm{Ma}$ and from $206 \mathrm{~Pb} / 207 \mathrm{~Pb}$ age for analyses with $206 \mathrm{~Pb} / 238 \mathrm{Uage}>900 \mathrm{Ma}$.

4. Concordance is based on $206 \mathrm{~Pb} / 238 \mathrm{U}$ age $/ 206 \mathrm{~Pb} / 207 \mathrm{~Pb}$ age. Value is not reported for $206 \mathrm{~Pb} / 238 \mathrm{U}$ ages $<500 \mathrm{Ma}$ because of large uncertainty in $206 \mathrm{~Pb} / 207 \mathrm{~Pb}$ age.

5. Analyses with $206 \mathrm{~Pb} / 238 \mathrm{U}$ age $>500 \mathrm{Ma}$ and with $>20 \%$ discordance $(<80 \%$ concordance) are not included.

6. Analyses with $206 \mathrm{~Pb} / 238 \mathrm{U}$ age $>500 \mathrm{Ma}$ and with $>5 \%$ reverse discordance $(<105 \%$ concordance) are not included.

7. All uncertainties are reported at the 1-sigma level, and include only measurement errors.

8. Systematic errors are as follows (at 2-sigma level): [sample 1: $2.5 \%(206 \mathrm{~Pb} / 238 \mathrm{U}) \& 1.4 \%$ $(206 \mathrm{~Pb} / 207 \mathrm{~Pb})]$ These values are reported on cells U1 and $\mathrm{W} 1$ of NUagecalc.

9. Analyses conducted by LA-MC-ICPMS, as described by Gehrels et al. (2008).

10. U concentration and U/Th are calibrated relative to Sri Lanka zircon standard and are accurate to $\sim 20 \%$.

11. Common $\mathrm{Pb}$ correction is from measured $204 \mathrm{~Pb}$ with common $\mathrm{Pb}$ composition interpreted from Stacey and Kramers (1975).

12. Common $\mathrm{Pb}$ composition assigned uncertainties of 1.5 for $206 \mathrm{~Pb} / 204 \mathrm{~Pb}, 0.3$ for $207 \mathrm{~Pb} / 204 \mathrm{~Pb}$, and 2.0 for $208 \mathrm{~Pb} / 204 \mathrm{~Pb}$.

13. $\mathrm{U} / \mathrm{Pb}$ and $206 \mathrm{~Pb} / 207 \mathrm{~Pb}$ fractionation is calibrated relative to fragments of a large Sri Lanka zircon of $563.5 \pm 3.2 \mathrm{Ma}(2$-sigma).

14. U decay constants and composition as follows: $238 \mathrm{U}=9.8485 \times 10-10,235 \mathrm{U}=1.55125 \times 10-10$, $238 \mathrm{U} / 235 \mathrm{U}=137.88$.

15. Weighted mean and concordia plots determined with Isoplot (Ludwig, 2008).

\section{References}

Amrouch, K.; Lacombe, O.; Bellahsen, N.; Daniel, J.M.; Callot, J.P., 2010, Stress and strain patterns, kinematics and deformation mechanisms in a basement-cored anticline:

Sheep Mountain Anticline, Wyoming. Tectonics 29. 
Anderson, J.J., Bastien, T.W., Craddock, C., Schmidt, P.G. \& Spletttoesser, J.F. 1962, "Antarctica; geology of the Ellsworth Mountains", Science, vol. 138, no. 3542, pp. 824-825.

Andersson, P.O.D., Worden, R.H., Hodgson, D.M. and Flint, S., 2004, Provenance evolution and chemostratigraphy of a Paleozoic submarine fan-complex: Tanqua Karoo Basin, South Africa: Marine and Petroleum Geology 21, p. 555-577.

Bauer, R.L. 1992, "Pretectonic burial metamorphism in the Heritage Group, southern Ellsworth Mountains, West Antarctica; Geology and paleontology of the Ellsworth Mountains, West Antarctica", Memoir - Geological Society of America, vol. 170, pp. 333-349.

Barbeau, D.L., J.T. Davis, K.E. Murray, V. Valencia, G.E. Gehrels, K. M. Zahid and D.J. Gombosi, 2009, Detrital zircon geochronology of the metasedimentary rocks of northwestern Graham Land: Antarctic Science p. 1-14.

Bickford, M.E., Wooden, J.L., and Bauer, R.L., 2006, SHRIMP study of zircon grains from Early Archean rocks in the Minnesota River Valley: implications for the tectonic history of the Superior Province: Geol. Soc. Am. Bull., v. 118, p. 94-108.

Boger, S.D, 2011, Antarctica-Before and After Gondwana: Gondwana Research 19, p. 335-371.

Buggisch, W. \& Webers, G.F. 1992, "Facies of Cambrian carbonate rocks, Ellsworth Mountains, West Antarctica; Geology and paleontology of the Ellsworth Mountains, West Antarctica", Memoir - Geological Society of America, vol. 170, pp. 81-100.

Buggisch, W., Webers, G.F., Repetski, J.E. \& Glenister, L. 1992, "Cambrian conodonts from the Springer Peak and Minaret formations, Ellsworth Mountains, West Antarctica; Geology and paleontology of the Ellsworth Mountains, West Antarctica", Memoir - Geological Society of America, vol. 170, pp. 169-179.

Burkhard, M., 1993. Calcite twins, their geometry, appearance and significance as stressstrain markers and indicators of tectonic regime: a review. Journal of Structural Geology 15, 351-368.

Burgess, S.D., S.A. Bowring, T.H. Fleming and D.H. Elliot, 2015, High-precision geochronology links Ferrar large igneous province with early Jurassic ocean anoxia and biotic crisis: Earth and Planetary Science Letters 415, p. 90-99.

Castle, J.W. and C. Craddock, 1975, Deposition and metamorphism of the Polarstar Formation (Permian), Ellsworth Mountains: Antarctic Journal of the United States 10, p. 239-41.

Cloos, E., 1947, Oolite deformation in the South Mountain fold, Maryland: Geol. Soc. Am. Bull. 58, p. 843-918.

Cobbold, P.R., D. Gapais and E.A. Rossello, 1991, Partitioning of transpressive motions within a sigmoidal foldbelt: The Variscan Sierras Australes, Argentina: Journal of Structural Geology 13, p. 743-758.

Cole, D.!., 1998, Paleogeography and paleocurrent distribution of the Beaufort Group in the Karoo Basin, South Africa, during the late Permian: Journal of African Earth Sciences 27, 1A, p. 46-7.

Collinson, J.W., Vavra, C.L. \& Zawiskie, J.M. 1992, "Sedimentology of the Polarstar Formation (Permian), Ellsworth Mountains, West Antarctica; Geology and paleontology of the Ellsworth Mountains, West Antarctica", Memoir - Geological Society of America, vol. 170, pp. 63-79.

Craddock, C. 1966, "Ellsworth mountains fold belt; a link between east and west Antarctica", Special Paper - Geological Society of America, vol. 87, pp. 37-38. 
Craddock, C. (1969). Geology of the Ellsworth Mountains. Geog. Soc. Antarctic Map Folio Series, Folio.

Craddock, C. (1970). Geologic maps of Antarctica. American Geographical Society.

Craddock, C. (1970). Tectonic map of Antarctica. Geologic Maps of Antarctica.-Antarctic Map Folio Ser., Folio,

Craddock, C. 1972, "Antarctic Tectonics; Antarctic geology and geophysics", International Union of Geological Sciences.Series B, vol. 1, pp. 449-455.

Craddock, C., Bastien, T.W., Rutford, R.H. \& and Anderson, J.J. 1965, "Glossopteris discovered in West Antarctica", Science, vol. 148, no. 3670, pp. 634-637.

Craddock, C., 1983, The East Antarctica-West Antarctica boundary between the ice sheets, in Oliver, R.L., James, P.R., and Jago, J.B., eds., Antarctic Earth Sciences: Cambridge, Cambridge University Press, p. 94-97.

Craddock, C., Webers, G.F., Rutford, R.H., Spo“rli, K.B., and Anderson, J.J., 1986, Geological Map of the Ellsworth Mountains, Antarctica: Boulder, Colorado, Geological Society of America Map and Chart Series MC-57, scale 1:250 000.

Craddock, C., Sporli, K.B. \& Anderson, J.J. 1992, "Structure of the Sentinel Range, Ellsworth Mountains, West Antarctica; Geology and paleontology of the Ellsworth Mountains, West Antarctica", Memoir - Geological Society of America, vol. 170, pp. 393-402.

Craddock, J.P., 1980, Stratigraphy and Structure of the Ellsworth Mountains, Antarctica: Senior thesis, Macalester College, St. Paul, MN, 35 pp.

Craddock, J.P., 2011, Provenance of Late Paleozoic Gondwana Tillites: Gondwana-14, Buzios, Brazil, p. 131.

Craddock, J.P., van der Pluijm, B.A., 1989. Late Paleozoic deformation of the cratonic carbonate cover of eastern North America. Geology 17, 416-419.

Craddock, J.P. and Pearson, A., 1994. Non-coaxial horizontal shortening strains preserved in amygdule calcite, DSDP Hole 433C, Suiko Seamount. Journal of Structural Geology 16, 719-724.

Craddock, J.P. and van der Pluijm, B., 1988, Kinematic analysis of an en echelon-continuous vein complex: Journal of Structural Geology, v. 10, p. 445-452.

Craddock, J. P. \& \#McKiernan, A.W., 2007, Tectonic implications of finite strain gradient in Baraboo-interval quartzites (ca. $1700 \mathrm{Ma}$ ), Mazatzal orogen, Wisconsin and Minnesota, USA: Precambrian Research, 156, p. 175-94.

Craddock, J.P., Moshoian, A., Pearson, A.M., 1991. Kinematic analysis from twinned calcite strains in the marble mylonites of the central Grenville province, Canada.

Geological Society of America, Abstracts with Programs 15, 236.

Craddock, J.P., Jackson, M., van der Pluijm, B.A., Versical, R., 1993, Regional shortening fabrics in eastern North America: far-field stress transmission from the Appalachian-Ouachita orogenic belt: Tectonics 12, 257-264.

Craddock, J.P., Pearson, A., McGovern, M., Kropf, E.P.,Moshoian, A., 
and Donnelly, K., 1997, Post-extension shortening strains preserved in calcites of the Keweenawan rift: Middle Proterozoic to Cambrian Rifting, Central North America, R.W. Ojakgangas, A.B. Dickas and J.C. Green (Eds.) Geological Society of America Special Paper 213 , p. 115-126.

Craddock, John P., Neilson, K. J. and Malone, D.H., 2000, Calcite twinning strain constraints on Heart Mountain detachment kinematics, Wyoming: Journal of Structural Geology, v. 22, p. 983-991.

Craddock, J.P. , Farris, D. and Roberson, A., 2004, Calcite-twinning constraints on stress-strain fields along the Mid-Atlantic Ridge, Iceland: Geology 32, n. 1, p. 49-52 (and two electronic repository files).

Craddock, J. P.,McKiernan, A., \& DeWit, M., 2007a, Calcite twin analysis in synorogenic calcite, Cape Fold Belt: implications for fold rotation and cleavage formation, Journal of Structural Geology, 27, p. 1100-1113.

Craddock, J.P., Anziano, J., Wirth, K.R., Vervoort, J.D., Singer, B. and Zhang, X., 2007b, Structure, geochemistry and geochronology of a lamprophyre dike swarm, Archean Wawa terrane, Michigan, USA: Precambrian Research, 157, p. 50-70.

Craddock, J.P., Konstantinou, A., Nereson, A., Webers, G.F., Ojakangas, R. W., Fitzgerald, P., and G. Gehrels, 2008a, Detrital Zircon and Heavy Mineral Provenance of the Ellsworth Mountains, Antarctica and Gondwana-wide Carboniferous Tillite: Gondwana 13 (Dali, China), p. 35.

Craddock, J.P., Juda, N.A., Crowley, J.L., Schmitz, M.D. and R.J. Pankhurst, 2008b, Precise U-Pb Zircon Ages from Central Antarctic Granites: Gondwana 13 (Dali, China), p. 34.

Craddock, J.P., Webers, G.F., \& McGillion, M.S., 2008, Major, trace element and stable isotope geochemistry of synorogenic breccia bodies, Ellsworth Mtns., Antarctica: U.S. Geological Survey \& The National Academies; USGS OF-2007-1047, doi:10.3133/of2007-1047.srp078.

Craddock, J.P., Klein, T., Kowalczyk, G. and Zulauf, G., 2009, Calcite twinning strains in Alpine orogen flysch: implications for thrust-nappe mechanics and the geodynamics of Crete:

Lithosphere v. 1; no. 3; p. 174-191, doi: 10.1130/L31.1.

Craddock, J.P. and Thomas, R., 2011, Detrital Zircon Provenance of the Dwyka Tillite, Cape Fold Belt, S. Africa and the Falkland Islands: GeoSynthesis Conference, Cape Town, S. Africa, p. 56-7.

Craddock, J.P., Geary, J., and D.H. Malone, 2012, Vertical Injectites of Detachment

Carbonate Ultracataclasite at White Mountain, Heart Mountain Detachment,

Wyoming: Geology v. 40, p. 463-466; doi: 10.1130/G32734.1

Craddock, J. P., Konstantinou, A., Vervoort, J.D., Wirth, K.R., Davidson, C., Finley-Blasi, L., Juda, N.A., and E. Walker, 2013, Detrital Zircon Provenance of the Proterozoic Midcontinent Rift, Lake Superior region, USA, Journal of Geology 121, p. 57-73.

Craddock,J.P., Rainbird, R., Davis, W.J., Heaman, L., Vervoort, J.D., Davidson, C., Boerboom, T., Konstantinou, A., Vorhies, S., Kerber, L., and Lundquist, R., 2013, Detrital Zircon Provenance of the Neoproterozoic ( 2.4-2.2 Ga) Huron and Paleoproterozoic ( 2.2-1.8 Ga) Animikie Basins, Southern Margin of Laurentia: Journal of Geology 121, p. 623-644.

Craddock, J.P., Schmitz, M.D., Crowley, J.L., Larocque, J., Pankhurst, R.J., Juda, N., Konstantinou, A., and B. Storey, 2016, Precise U-Pb zircon ages and geochemistry of Jurassic granites, EllsworthWhitmore terrane, central Antarctica. Geological Society of America Bulletin 113, p. xx-yy, doi: 10.113/B31485.1; 8 figures, 5 tables; Data Repository item 2016236. 
Craddock, S.D. and J.P. Craddock, 2012, Strain Variations in Carbonates across the Proterozoic

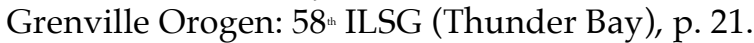

Curtis, M.L., 1997, Gondwanian age dextral transpression and spatial kinematic partitioning within the Heritage Range, Ellsworth Mountains, West Antarctica: Tectonics,

v. 16, p. $172-181$.

Curtis, M.L., 1998, Development of kinematic partitioning in a pure-shear dominated dextral transpression zone: the southern Ellsworth Mountains, Antarctica, in Holdsworth, R.E., et al., eds., Continental transpressional and transtensional tectonics: Geological Society

[London] Special Publication 135, p. 289-306.

Curtis, M.L., 2001, Tectonic history of the Ellsworth Mountains, West Antarctica: Reconciling a Gondwana enigma: Geological Society of America Bulletin, v. 113, p. 939-958, doi: 10.1130/00167606(2001)113<0939: THOTEM>2.0.CO;2.

Curtis, M.L., and Storey, B.C., 1996, A review of geological constraints on the pre-break-up position of the Ellsworth Mountains within Gondwana: Implications for Weddell Sea evolution, in Storey, B.C., King, E.C., and Livermore, R.A., eds., Weddell Sea Tectonics and Gondwana Break-up: Geological Society of London Special Publication 135, p. 289-306.

Curtis, M.L., and Lomas, S.A., 1998, Late Cambrian stratigraphy of the Heritage Range, Ellsworth Mountains; implications for basin evolution: Antarctic Science, v. 11, p. 63-77.

Curtis, M.L., Leat, P.T., Riley, T.R., Storey, B.C., Millar, I.L., and Randall, D.E., 1999a, Middle Cambrian volcanism in the Ellsworth Mountains: Implications for paleo-Pacific margin tectonics: Tectonophysics, v. 304, p. 275-299.

Curtis, M.L., Leat, P.T., Riley, T.R., Storey, B.C., Millar, I.L., and Randall, D.E., 1999b, Middle Cambrian rift-related volcanism in the Ellsworth Mountains, Antarctica: Tectonic implications for the palaeo-Pacific margin of Gondwana: Tectonophysics, v. 304, p. 275-299,doi: 10.1016/S00401951(99)00033-5.

Dalziel, I.W.D., 1991, Pacific margins of Laurentia and East Antarctica as a conjugate rift pair: Evidence and implications for an Eocambrian supercontinent: Geology, v. 19, p. 598-601, doi:10.1130/0091-7613(1991)019<0598:PMOLAE>2.3.CO;2.

Dalziel, I.W.D., 1992, Antarctica; a tale of two supercontinents?: Annual Review of Earth and Planetary Sciences, v. 20, p. 501-526, doi:10.1146/annurev.ea.20.050192.002441.

Dalziel, I.W.D., 1997, Neoproterozoic-Paleozoic geography and tectonics: Review, hypothesis, environmental speculation: Geological Society of America Bulletin, v. 109, p. 16-42, doi:10.1130/0016-7606(1997)109<0016:ONPGAT>2.3.CO;2.

Dalziel, I.W.D, 2008, The Ellsworth Mountains: Critical and enduringly enigmatic: U.S. Geological Survey and The National Academies: USGS OF-2007-1047, Short Research Paper 004.

Dalziel, I.W.D., and Elliot, D.H., 1982, West Antarctica: Problem child of Gondwanaland: Tectonics, v. 1, p. 3-19.

Dalziel, I.W.D., Garrett, S.W., Grunow, A.M., Pankhurst, R.J., Storey, B.C. \& Vennum, W.R. 1987, "The Ellsworth-Whitmore mountains crustal block; its role in the tectonic evolution of West Antarctica; Gondwana Six; Structure, tectonics, and geophysics", Geophysical Monograph, vol. 40, pp. 173-182.

Denton, G.H., Bockheim, J.G., Ritford, R.H. and B.G. Anderson, 1992 Glacial History of the Ellsworth Mountains, West Antarctica; Geology and paleontology of the Ellsworth Mountains, West Antarctica", Memoir - Geological Society of America, vol. 170, pp. 403-432. 
De Wit, M. J., \& Ransome, I. G. (1992). Regional inversion tectonics along the southern margin of Gondwana. Inversion tectonics of the Cape Fold Belt, Karoo and Cretaceous basins of southern Africa, 15-21.

Duebendorfer, E.M., and Rees, M.N., 1998, Evidence for Cambrian deformation in the EllsworthWhitmore Mountains terrane, Antarctica: Stratigraphic and tectonic implications: Geology, v. 26, p. 55-58, doi: 10.1130/0091-7613(1998)026<0055:EFCDIT>2.3.CO;2.

DuToit, A.L., 1937, Our Wandering Continents: Edinburgh, Scotland, Oliver \& Boyd, 355 p.

Engelder, T., 1979. The nature of deformation within the outer limits of the central Appalachian foreland fold-and-thrust belt in New York state. Tectonophysics 55, 289-310.

Engelder, T and Engelder, R., 1977, Fossil distortion and decollement tectonics of the Appalachian plateau: Geology 5, p. 457-460.

Evans, Mark A. and Groshong, Richard H. 1994. "A Computer Program for the Calcite Strain-Gage Technique." Journal of Structural Geology 16 (2): 277-281.

Elliot, D. H., Fleming, T.H., Kyle, P.R., and K.A. Foland, 1999, Long-distance transport of magmas in the Jurassic Ferrar Large Igneous Province, Antarctica: EPSL 167, p. 89-104.

Elliot, D.H., and Fleming, T.H., 2000, Weddell triple junction: The principal focus of Ferrar and Karoo magmatism during initial breakup of Gondwana: Geology, v. 28, p. 539-542.

Elliot, D.H., Fanning M. and T.S. Laudon, 2014, The Gondwana Plate margin in the Weddell Sea sector: zircon geochronology of the upper Paleozoic (mainly Permian) strata of the Ellsworth Mountains and eastern Ellsworth Land, Antarctic: Gondwana Research, http:// dx.doi.org/10.1016/j.gr.2014.12.001

Ferrill, D.A., 1991. Calcite twin widths and intensities as metamorphic indicators in natural low-temperature deformation of limestone. Journal of Structural Geology v. 13, 675-677.

Ferrill, D.A., 1998. Critical re-evaluation of differential stress estimates from calcite twins in coarse-grained limestone. Tectonophysics 285, 77-86.

Ferrill, David A., Alan P. Morris, Mark A. Evans, Martin Burkhard, Richard H. Groshong, and Charles M. Onasch. 2004. "Calcite Twin Morphology: A LowTemperature Deformation Geothermometer." Journal of Structural Geology 26 (8): 1521-1529.

Fitzgerald, P.G. \& Stump, E. 1991, "Early Cretaceous uplift in the Ellsworth Mountains of West Antarctica", Science, vol. 254, no. 5028, pp. 92-94.

Fildani, A. (and 7 others), 2010, U-Pb ages from the southwestern Karoo Basin, South Africaimplications for the Permian-Triassic boundary: Geology 37, p. 719-722.

Flowerdew, M.J., Millar, I.L., Vaughan, A.P.M., Horstwood, M.S.A., and Fanning, C.M., 2006, The source of granitic gneisses and migmatites in the Antarctic Peninsula: A combined U-Pb SHRIMP and laser ablation Hf isotope study of complex zircons: Contributions to Mineralogy and Petrology, v. 151, p. 751-768, doi:10.1007/s00410-006-0091-6.

Flowerdew, MJ, IL Millar, ML Curtis, APM Vaughan, M.S.A. Horstwood, M.J. Whitehouse and C.M Fanning, 2007, Combined U-Pb geochronology and Hf isotope geochemistry of detrital 
zircons from early Paleozoic sedimentary rocks, Ellsworth-Whitmore Mountains block, Antarctica: Geological Society of America Bulletin 119, p. 275-288.

Gehrels, G.E., Valencia, V., Ruiz, J., 2008, Enhanced precision, accuracy, efficiency, and spatial resolution of $\mathrm{U}-\mathrm{Pb}$ ages by laser ablation-multicollector-inductively coupled plasma-mass spectrometry: Geochemistry, Geophysics, Geosystems, v. 9, Q03017, doi:10.1029/2007GC001805.

Goldstrand, P.M., Fitzgerald, P.G., Redfield, T.F., Stump,E., and Hobbs, C., 1994, Stratigraphic evidence for the Ross orogeny in the Ellsworth Mountains, West Antarctica: Implication for the evolution of the paleo-Pacifi c margin of Gondwana: Geology, v. 22, p. 427-430, doi: 10.1130/ 0091-7613(1994)022<0427: SEFTRO>2.3.CO;2.

Goodge, J.W., Vervoort, J.D., Fanning, C.M., Brecke, D.M., Farmer, G.L., Williams, I.S., Myrow, P.M., and DePaolo, D.J., 2008, A positive test of East Antarctica-Laurentia juxtaposition within the Rodinia supercontinent: Science, v. 321, p. 235-240, doi:10.1126/ science.1159189.

Goodge, J. W., Fanning, C. M., Brecke, D. M., Licht, K. J., and Palmer, E. F., 2010, Continuation of the Laurentian Grenville province in western East Antarctica; Journal of Geology, v. 118, p. 601-619.

Goodge, J.W. and C.M. Fanning, 2012, Composition and age of the East Antarctic Shield in eastern Wilkes Land determined by proxy from Oligocene-Pleistocene glaciomarine sediment and Beacon Supergroup sandstone, Antarctica: Geological Society of America Bulletin 122, p. 1135-1159.

Gray, Mary Beth, John A. Stamatakos, David A. Ferrill, and Mark A. Evans. 2005.

"Fault-Zone Deformation in Welded Tuffs at Yucca Mountain, Nevada, USA."

Journal of Structural Geology 27 (10): 1873-1891.

Groshong, R.H., Jr. 1972, Strain calculated from twinning in calcite: Bull. geol. Soc. Am. 83, 2025-2038.

Groshong, R.H., Jr. 1974, Experimental test of least-squares strain calculations using twinned calcite: Bull. Geol. Soc. Am. 85, 1855-1864.

Groshong, R.H., Jr., 1975, Strain, fractures, and pressure solution in natural single-layer folds. Bull. geol. Soc. Am. 86, 1363-1376.

Groshong R.H., Jr., 1976, Strain and pressure solution in the Martinsburg slate, Delaware Water Gap, New Jersey: Amer. J. Sci. 276, p. 1131-1146.

Groshong, R.H. Jr, Teufel, L.W., Gasteiger, C.M., 1984. Precision and accuracy of the calcite strain-gage technique. Bulletin of the Geologic Society of America 95, 357-363.

Grunow, A.M., Dalziel, I.W.D. \& Kent, D.V. 1987, "Ellsworth-Whitmore mountains crustal block, western Antarctica; new paleomagnetic results and their tectonic significance; Gondwana Six; Structure, tectonics, and geophysics", Geophysical Monograph, vol. 40, pp. 161-171.

Grunow, A.M., 1993, Creation and destruction of Weddell Sea floor in the Jurassic: Geology, v. 21, p. 647-650.

Halbich, I.W., 1992, The Cape fold belt orogeny: state of the art 1970s-1980s: in Inversion Tectonics of the Cape Fold Belt, Karoo and Cretaceous Basins of Southern Africa (Rotterdam), p. $141-158$.

Harley, S.L. and N.M. Kelley, 2007, Ancient Antarctica: The Archean of the East Antarctic Shield: in, Earth's Oldest Rocks, Developments in Precambrian Geology , v. 15, p. 149-186. 
Hiller, N. and F.F. Taylor, 1992, Late Devonian shoreline changes: an analysis of Witteberg stratigraphy in the Grahamstown area, S. Africa: Journal of Geology 95, p. 203-12.

Huebscher, C., Jokat, W. and H. Miller, 1996, Crustal structure of the Antarctic continental margin in the eastern Weddell Sea: Weddel Sea Tectonic and Gondwana Break-up, Geological Society Special Publication 108, p. 165-74.

Jacobs, J., Fanning, C.M., and Bauer, W., 2003, Timing of Grenville-age vs. Pan-African mediumto high-grade metamorphism in western Dronning Maud Land (East Antarctica) and significance for correlations in Rodinia and Gondwana: Precambrian Research, v. 125, p. 1-20, doi: 10.1016/S0301-9268(03)00048-2.

Jago, J.B. \& Webers, G.F. 1992, "Middle Cambrian trilobites from the Ellsworth Mountains, West Antarctica; Geology and paleontology of the Ellsworth Mountains, West Antarctica", Memoir Geological Society of America, vol. 170, pp. 101-124.

Jell, P.A., 1975, Australian middle Cambrian eodiscoids with a review of the super family: Paleontographica A 150, p. 1-97.

Kilsdonk, W., Wiltschko, D.V., 1988. Deformation mechanisms in the southeastern ramp region of the Pine Mountain block, Tennessee. Geological Society of America Bulletin 100, 644-653.

Konstantinou, A., Wirth, K.R., Vervoort, J.D., Davidson, C., Malone, D.H. and Craddock, J.P., 2014, Detrital zircon geochronology of Early Paleozoic Midcontinent region, supermature quartz arenites: Implications for paleogeography, erosion and sedimentation patterns: Journal of Geology 122, p. 201-216.

Kyle, P.R., 1980, Development of heterogeneities in the subcontinental mantle: evidence from the Ferrar group, Antarctica: Contrib. Mineral. and Petrology, v. 73, p. 89-104.

Lacombe, O., Laurent, P., 1996. Determination of deviatoric stress tensors based on inversion of calcite twin data from experimentally deformed monophase samples: preliminary results. Tectonophysics $255,189-202$.

Lawver, L.A., Sandwell, D.A., Royer, J.-Y., Scotese, C.R., 1991, Evolution of the Antarctic continental margins, in: Thomson, M.R.A., Crame, J.A., Thomson, J.W. (Eds.), Geological Evolution of Antarctica, Cambridge Univ. Press, p. 533-540.

Loewy, S.L., Dalziel, I.W.D., Pisarevsky, S., Connelly, J.N., Tait, J., Hanson, R.E. and D. Bullen, 2011, Coats Land crustal block, East Antarctica: a tectonic tracer for Laurentia?: Geology 39, p. $859-62$.

Lopez-Gamundi, O.R., and Buatois, L.A., 2010, Introduction: Late Paleozoic glacial events and postglacial transgressions in Gondwana, in Lopez-Gamundi, O.R., and Buatois, L.A., eds., Late Paleozoic Glacial Events and Postglacial Transgressions, in Gondwana: Geological Society of America Special Paper 468, p. v-viii.

Ludwig, K., 2008, Isoplot 3.6: Berkeley Geochronology Center Special Publication 4, 77 p.

Maslanyj, M.P. \& Storey, B.C. 1990, "Regional aeromagnetic anomalies in Ellsworth Land; crustal structure and Mesozoic microplate boundaries within West Antarctica", Tectonics, vol. 9, no. 6, pp. 1515-1532.

Matsch, C.L. \& Ojakangas, R.W. 1992, "Stratigraphy and sedimentology of the Whiteout Conglomerate; an upper Paleozoic glacigenic unit, Ellsworth Mountains, West Antarctica; Geology and paleontology of the Ellsworth Mountains, West Antarctica", Memoir - Geological Society of America, vol. 170, pp. 37-62. 
McKay, M.P., Weislogel, A.L., Fildani, A., Brunt, R.L., Hodgson, D.M. and S.S. Flint, 2015, U-Pb zircon tuff geochronology from the Karoo Basin, South Africa: implications of zircon recycling on stratigraphic age controls: International Geology Review 57, p. 393-410.

Millar, I.L. \& Pankhurst, R.J. 1987, "Rb-Sr geochronology of the region between the Antarctic Peninsula and the Transantarctic Mountains; Haag Nunataks and Mesozoic granitoids; Gondwana Six; Structure, tectonics, and geophysics", Geophysical Monograph, vol. 40, pp. 151160.

Millar, I.L., Willan, R.C.R., Wareham, C.D. \& Boyce, A.J. 2001. The role of crustal and mantle sources in the genesis of granitoids of the Antarctic Peninsula and adjacent crustal blocks. Journal of the Geological Society, 158, 855-867.

Millar, I.L., Pankhurst, R.J. \& Fanning, C.M. 2002. Basement chronology of the Antarctic Peninsula: recurrent magmatism and anatexis in the Palaeozoic Gondwana margin. Journal of the Geological Society, 159, 145-157.

Miller, W., Armstrong, R. and M.J. de Witt, 2016, Geology and U/Pb geochronology of the Gomtoos Complex and lower Paleozoic Table Mountain Group, Cape Fold Belt, eastern Cape, South Africa: South African Journal of Geology 119.1, p. 147-170.

Minor, D., and Mukasa, S.B., 1997, Zircon U-Pb and hornblende 40Ar/39Ar ages for the Dufek layered mafic intrusion, Antarctica: implications for the age of the Ferrar large igneous province: Geochim. Cosmochim. Acta, v. 61, p, 2497-2504.

Moores, E.M., 1991, Southwest U.S-East Antarctica (SWEAT) connection: A hypothesis: Geology, v. 19, p. 425-428, doi:10.1130/0091-7613(1991)019<0425:SUSEAS>2.3.CO;2.

Mosar, J., 1989, Internal deformation in the Prealpes Medianes, Switzerland: Ecologae Geologicae Helvetiae, v. 82, p. 765-793.

Nickelsen. R.P., 1966, Fossil distortion and penetrative rock deformation in the Appalachian plateau, Pennsylvania: J. Geology 74, p. 924-31.

Paulsen, T.S., Encarnacion, J., Grunow, A.M., Layer, P.W., and M. Watkeys, 2007, New age contstraints for a short pulse in Ross orogeny deformation triggered by East-West Gondwana suturing: Gondwana Research 12, p. 417-427.

Paulsen, T.S., Wilson, T.J., Demosthenous, C., Millan, C., Jarrad, R. and A. Laufer, 2014, Kinematics of the Neogene Terror rift: constraints from calcite twinning strains in the ANDRILL McMurdo Ice Shelf (AND-1B) core, Victoria Land Basin, Antarctica: Geosphere 10, p. 828-841.

Paulsen, T.S., Deering, C., Slinski, J., Bachmann, O. and M. Guillong, 2016, Detrital zircon ages from the Ross Supergroup, north Victoria Land, Antarctica: implications for te tectonostratigraphic evolution of the Pacific-Gondwana margin: Gondwana Research 35, p. 79-96.

Rainbird, R. H.; Heaman, L. M.; and Young, G. 1992, Sampling Laurentia: detrital zircon geochronology offers evidence for an extensive Neoproterozoic river system originating from the Grenville orogen. Geology 20:351-354.

Randall, D.E., Curtis, M.L., and Millar, I.L., 2000, A new late Middle Cambrian palaeomagnetic pole for the Ellsworth Mountains, Antarctica: The Journal of Geology, v. 108, p. 403-425, doi: $10.1086 / 314408$.

Randall, D.E., and Mac Niocaill, C., 2004, Cambrian palaeomagnetic data confirm a Natal location for the Ellsworth-Whitmore Mountains, Antarctica, in Gondwana reconstructions: 
Geophysical Journal International, v. 157, p. 105-116, doi: 10.1111/j.1365-246X.2004.02192.x.

Rees, M.N., and Duebendorfer, E.M., 1997, Pan-African and Gondwanide deformations in the Ellsworth-Whitmore-Mountains terrane, Antarctic: Stratigraphic and regional implications: Christchurch, New Zealand,Terrane dynamics-97, Abstracts, p. 144-147.

Rees, M.N., Smith, E.I., Duebendorfer, E.M., and Keenan,D., 1998, Cambrian marginal basin rifting and subduction recorded in the Ellsworth-Whitmore Mountains terrane, West Antarctica: Journal of African Earth Sciences, v. 27, p. 151-153.

Rowe, K.J., Rutter, E.H., 1990. Paleostress estimation using calcite twinning: experimental calibration and application to nature. Journal of Structural Geology $12,1-17$.

Schopf, J.M. 1969, "Ellsworth mountains; position in west Antarctica due to sea-floor spreading", Science, vol. 164, no. 3875, pp. 63-66.

Schmitz, M.D., Southwick, D.L., Bowring, S.A., Boerboom, T.R., and Wirth, K.R., 2006, Highprecision $\mathrm{UPb}$ geochronology in the Minnesota River Valley subprovince and its bearing on the Neoarchean to Paleoproterozoic evolution of the southern Superior Province: Geol. Soc. Am. Bull. v. 118, p. 82-93.

Sporli, K.B. 1992, "Stratigraphy of the Crashsite Group, Ellsworth Mountains, West Antarctica; Geology and paleontology of the Ellsworth Mountains, West Antarctica", Memoir - Geological Society of America, vol. 170, pp. 21-35.

Sporli, K.B. \& Craddock, C. 1992a, "Stratigraphy and structure of the Marble, Independence, and Patriot Hills, Heritage Range, Ellsworth Mountains, West Antarctica; Geology and paleontology of the Ellsworth Mountains, West Antarctica", Memoir - Geological Society of America, vol. 170, pp. 351-364.

Sporli, K.B. \& Craddock, C. 1992b, "Structure of the Heritage Range, Ellsworth Mountains, West Antarctica; Geology and paleontology of the Ellsworth Mountains, West Antarctica", Memoir Geological Society of America, vol. 170, pp. 375-392.

Sporli, K.B., Craddock, C., Rutford, R.H. \& Craddock, J.P. 1992, "Breccia bodies in deformed Cambrian limestones, Heritage Range, Ellsworth Mountains, West Antarctica; Geology and paleontology of the Ellsworth Mountains, West Antarctica", Memoir - Geological Society of America, vol. 170, pp. 365-374.

Stacey, J.S., and Kramers, J.D., 1975, Approximation of terrestrial lead isotope evolution by a two stage model: Earth and Planetary Science Letters, v. 26, p. 207-221.

Storey, B.C and D.I.M. MacDonald, 1987, Sedimentary rocks of the Ellsworth-Thiel Mountains Ridge and the regional equivalents: British Antarctic Survey Bulletin 76, p. 21-49.

Storey, B.C., Dalziel, I.W.D., Garrett, S.W., Grunow, A.M., Pankhurst, R.J., and Vennum, W.R., 1988a, West Antarctica in Gondwanaland: Crustal blocks, reconstruction and breakup processes: Tectonophysics, v. 155, p. 381-390, doi: 10.1016/0040-1951(88)90276-4.

Stump, E., 1992, Ross orogeny of the Transantarctic Mountains:New York, Cambridge University Press, $284 \mathrm{p}$.

Spang, J.H. and Groshong, R.H., Jr., 1981, Deformation mechanisms and strain history of a minor fold from the Appalachian Valley and Ridge Province: Tectonophysics

$72,323-342$. 
Tankard, A.J. and J.H. Barwis, 1982, Wave-dominated deltaic sedimentation in the Devonian Bokkeveld Basin of South Africa: J. of Sedimentary Petrology 52, 959-974.

Teufel, L.W., 1980. Strain analysis of experimental superposed deformation using calcite twin lamellae. Tectonophysics 65, 291-309.

Torsvik, T. H.; Smethurst, M. A.; Meert, J. G.; Van der Voo, R.; McKerrow, W. S.; Brasier, M. D.; Sturt, B. A.; andWalderhaug, H. J. 1996. Continental break-up and collision in the Neoproterozoic and Palaeozoic —a tale of Baltica and Laurentia. Earth Sci. Rev. 40:229-258.

Turner, F.J., 1953. Nature and dynamic interpretation of deformation lamellae in calcite of three marbles. American Journal of Science 251, 276-298.

Turner FJ, 1962,Compression and tension axes deduced from (0112) Twinning in calcite.

J Geophys Res 67:1660.

Van Staal 1998

Visser, J.N.J., 1987, The palaeogeography of part of southwestern Gondwana during he PermoCarboniferous: Palaegeography, Palaeclimatology, Palaeoecology 61, p. 205-19.

Veevers and Saeed, 2011 GR

Von Gosen, W., W. Buggisch and L.V. Dimieri, 1990, Structural and metamorphic evolution of the Sierras Australes (Buenos Aires province, Argentina): Geologische Rundschau 79, p. 797-821.

Watts, D.R. \& Bramall, A.M. 1981, "Paleomagnetic evidence for a displaced terrain in western Antarctica", Nature (London), vol. 293, no. 5834, pp. 638-641.

Webers, G.F., Bauer, R.L., Anderson, J.M., Buggisch, W., Ojakangas, R.W. \& Spoerli, K.B. 1992, "The Heritage Group of the Ellsworth Mountains, West Antarctica; Geology and paleontology of the Ellsworth Mountains, West Antarctica", Memoir - Geological Society of America, vol. 170, pp. 9-19.

Wenk, H-R, T. Takeshita, E. Bechler, BG Erskine, and S. Matthies. 1987. "Pure Shear and Simple Shear Calcite Textures. Comparison of Experimental, Theoretical and Natural Data." Journal of Structural Geology 9 (5): 731-745.

Wiltschko, D.V., Medwedeff, D.A., Millson, H.E., 1985. Distribution and mechanisms of strain within rocks on the northwest ramp of Pine Mountain block, southern Appalachian foreland: a field test of theory. Geological Society of America Bulletin 96, 426-435. 


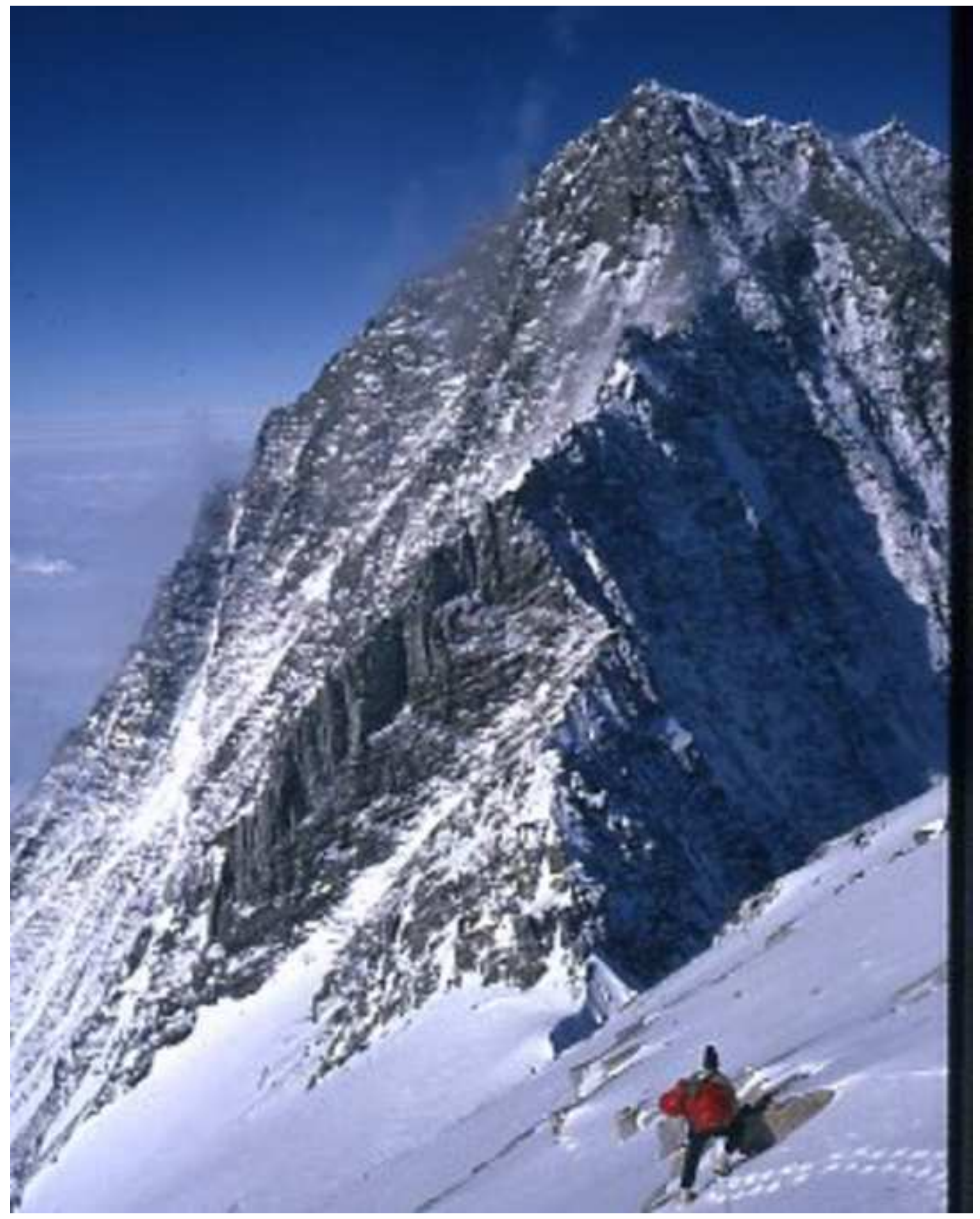

$\sin +8, \mathbb{R}$ 


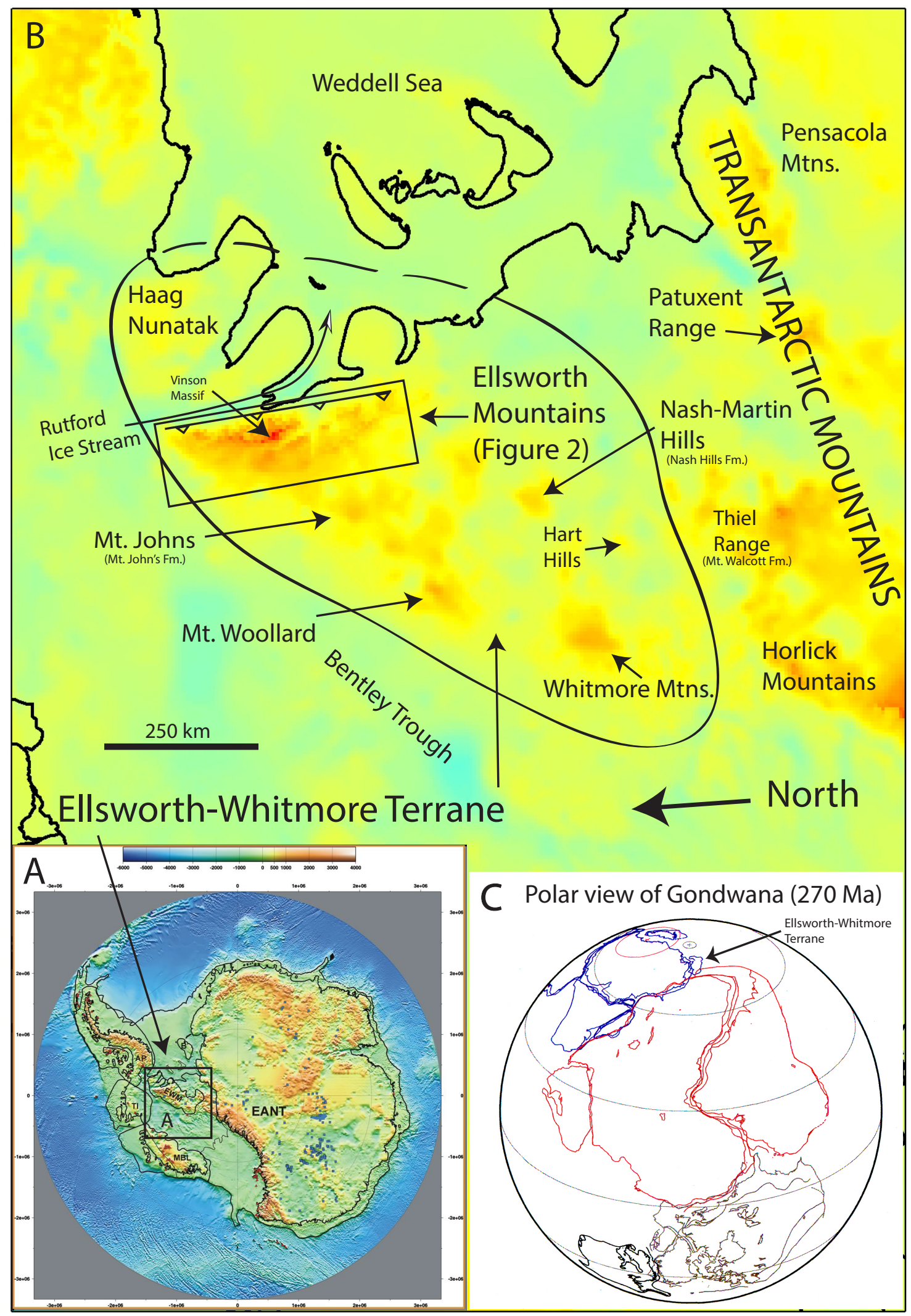

Figure 1: Sub-ice topographic DEM of Antarctica (A) with continental crust terranes identified (EANT: East Antarctic craton; AP: Antarctic Peninsula; TI: Thurston Island; MBL: Marie Byrd Land; EWM: Ellsworth-Whitmore Mountains; from Dalziel, 2008) and in (B), a detailed sub-ice DEM of central west Antarctica. Red-orange areas are exposed above ice whereas yellow areas are sub-ice and blue areas are below sea level. The Ellsworth Mountains are the highest peaks and were uplifted by a SW-dipping series of thrusts faults. Inset $C$ shows the relative position of the Ellsworth-Whitmore terrane in the Permian (Dalziel, 1997). 

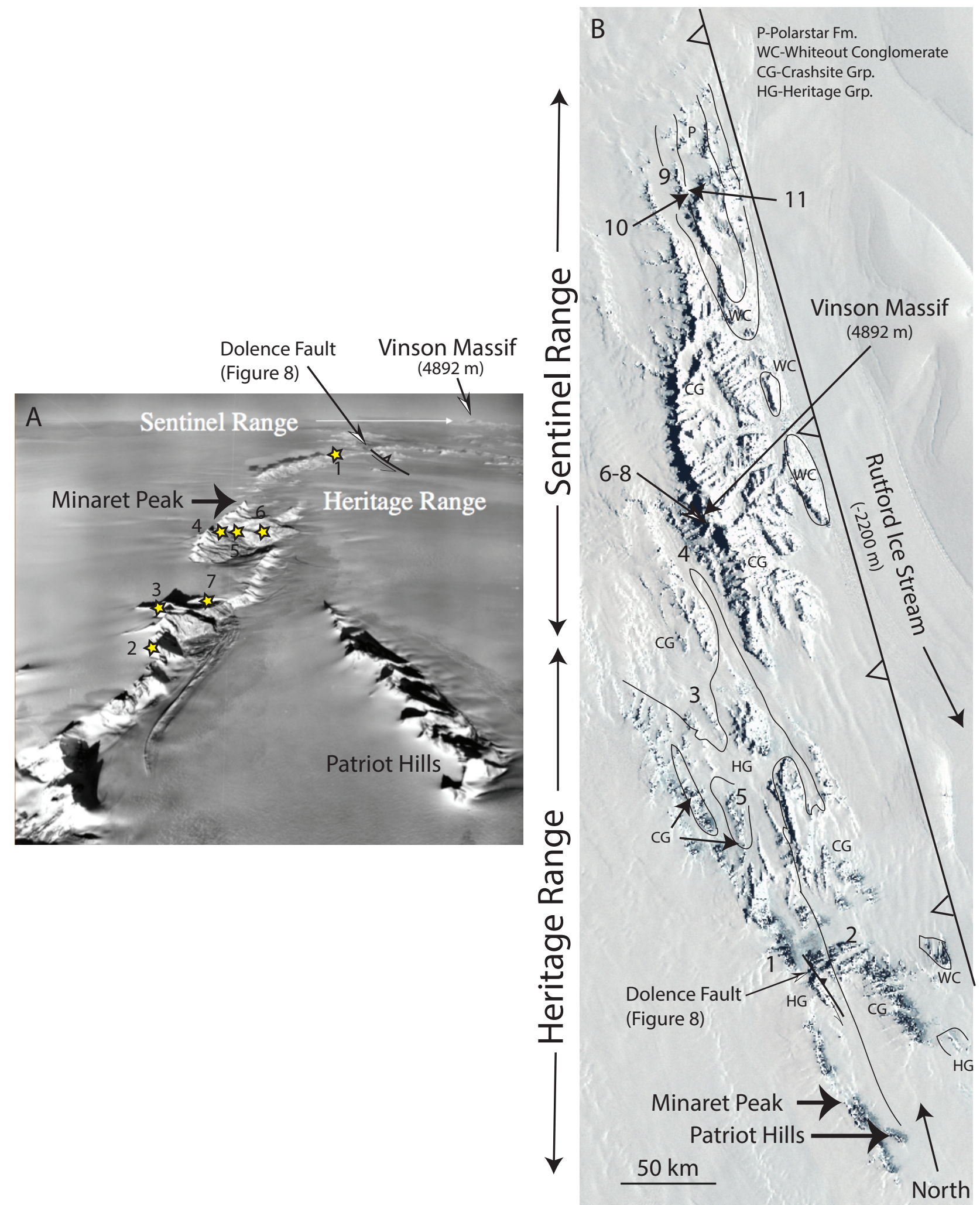

Figure 2: A. Oblique aerial image of the Ellsworth Mountains looking north from the southern Heritage Range. Calcite strain sites are identified with stars (Fig. 5, Table 2). The Patriot Hills and Minaret Peak are identified in this image, and for reference in B, the shaded relief map of the Ellsworth Mountains, Antarctica showing the lower, southerly Heritage Range and the high peaks of the Sentinel Range. The Gondwanide thrust margin and transport direction is indicated (see Curtis, 1990). Detrital zircon samples sites are indicated (See Table 1, Figure 3). Samples 1,2 and 9 are from Flowerdew et al. (2007). A detailed geologic map of the range is found in Craddock et al. (1986). 


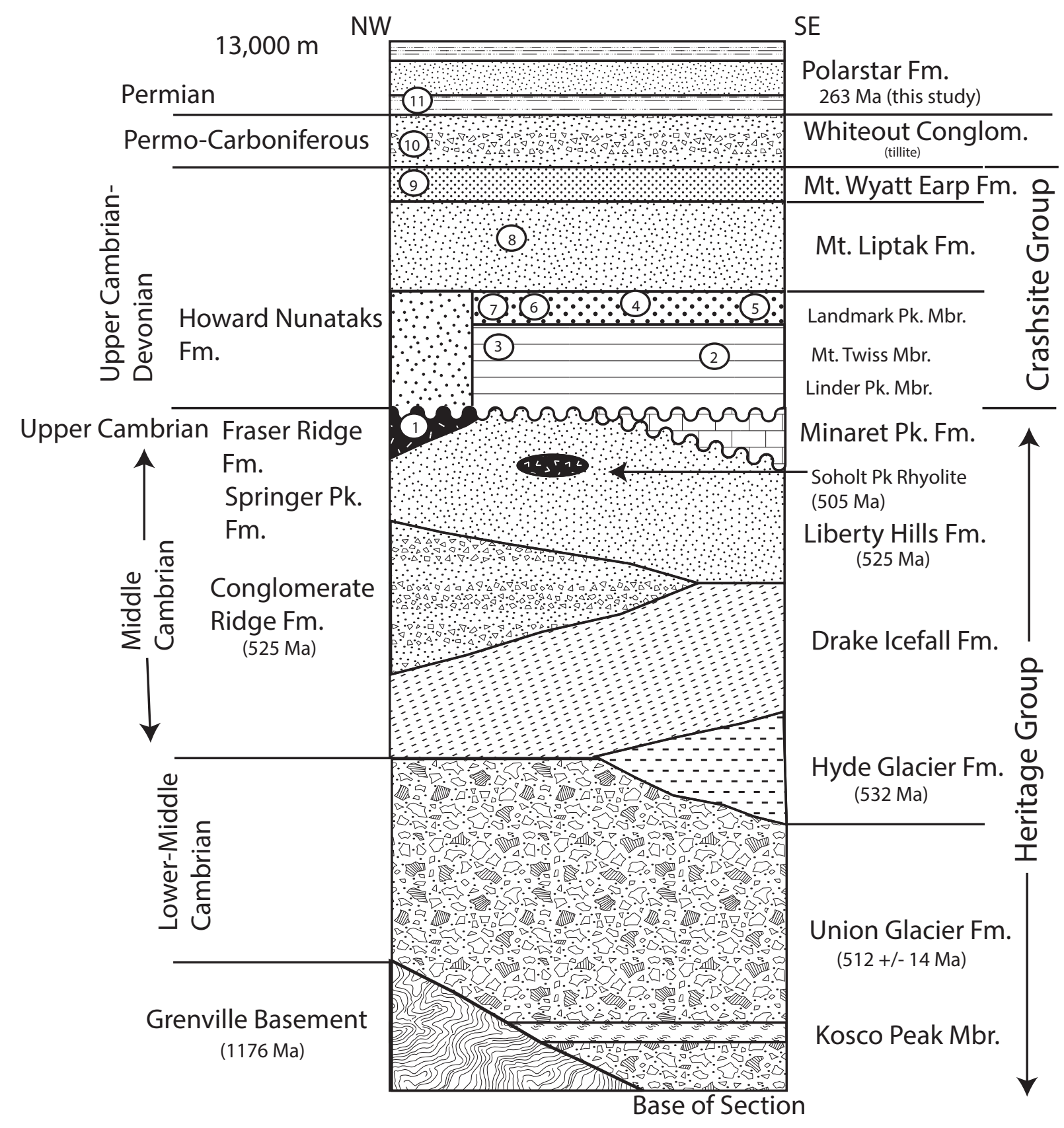

Figure 3: Stratigraphic column for the Ellsworth Mountains, Antarctica based on Webers et al. (1992) and Flowerdew et al. (2007). Radiometric ages are from Rees and Duebendorfer (1997), Rees et al. (1998) and Randall et al. (2000). Numbers in the column indicate detrital zircon samples from Figure 2 (see also Tables 1 and Appendix 2); samples 1, 2 and 9 are from Flowerdew et al. (2007). Calcite twinning strains are from the Minaret Pk. Fm. (Figure 5, Table 2). 


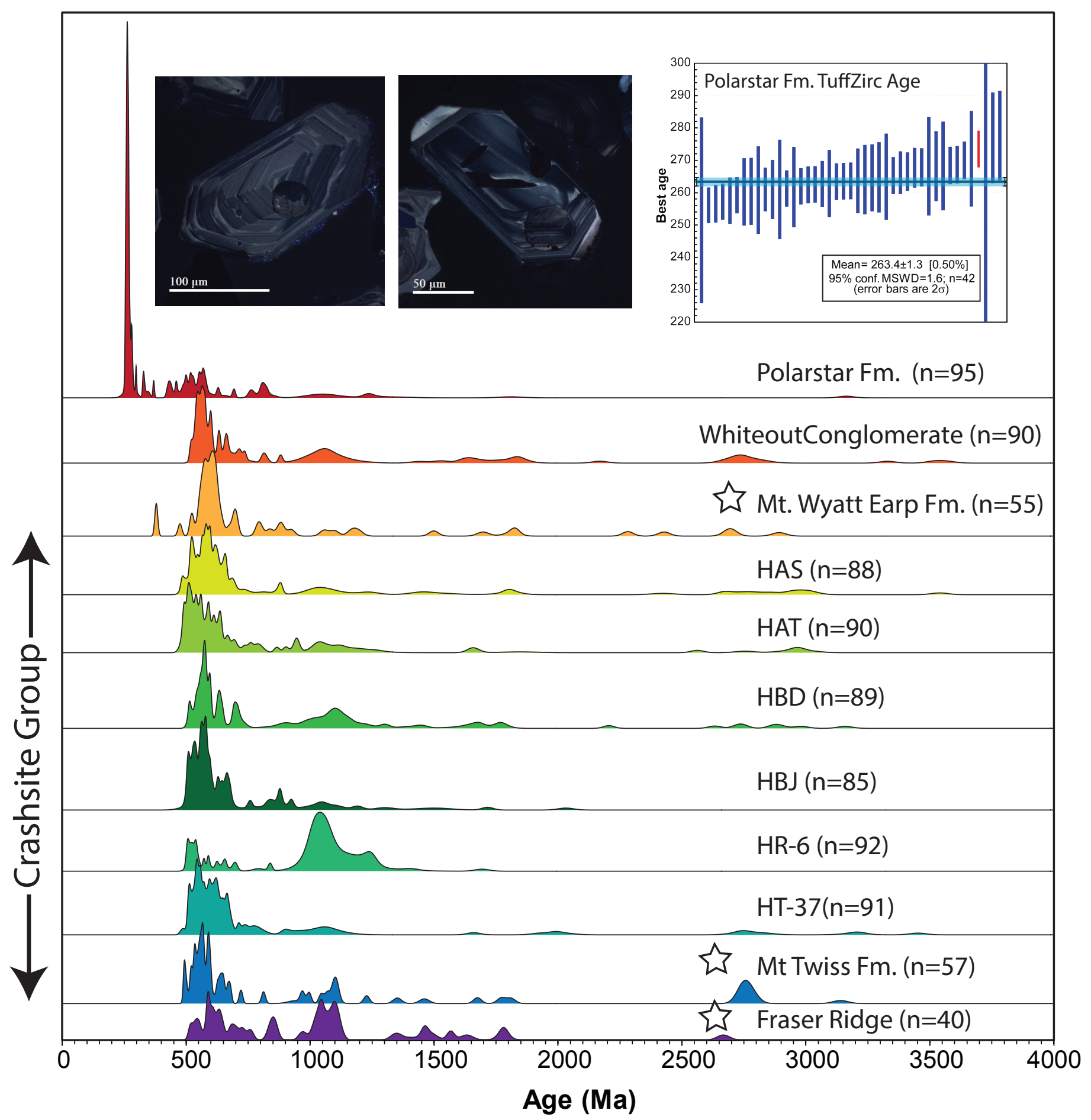

Figure 4: Summary relative probability plot for the Ellsworth Mountains, Antarctica including data from Flowerdew et al. (2007; open star symbol). Euhedral zircons (CL images above, with laser ablation holes) from the Polarstar Fm. produced a depositional age of $263 \mathrm{Ma}$. See Tables 1 and Appendix 2. 

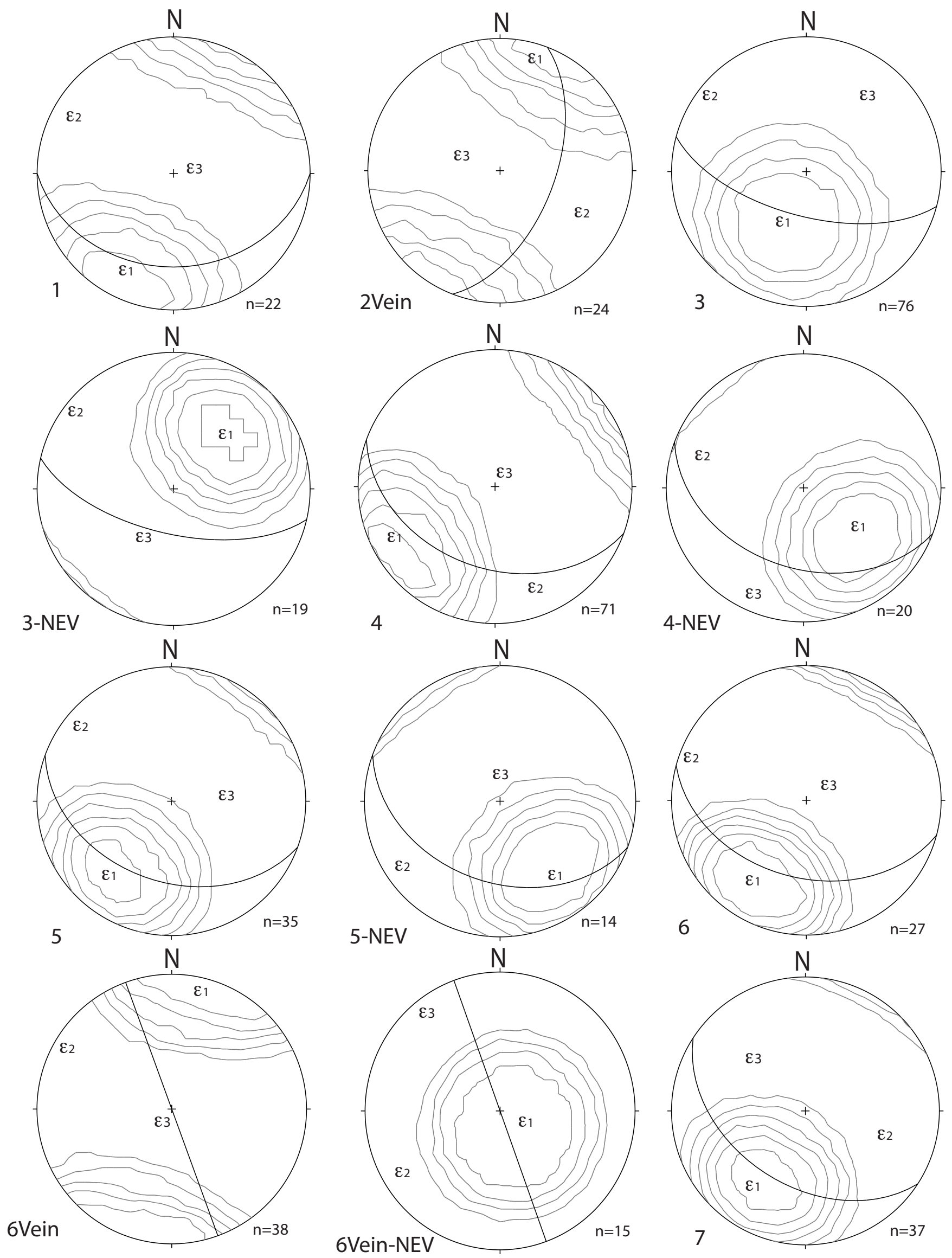

Figure 5: Lower hemisphere projections of calcite twinning strain data (Table 2) for the Minaret Fm. limestones and veins. Turner (1953) compression axes are contoured. Strain axes: e1= maximum shortening axis; e2= intermediate axis; e3= extension axis. 

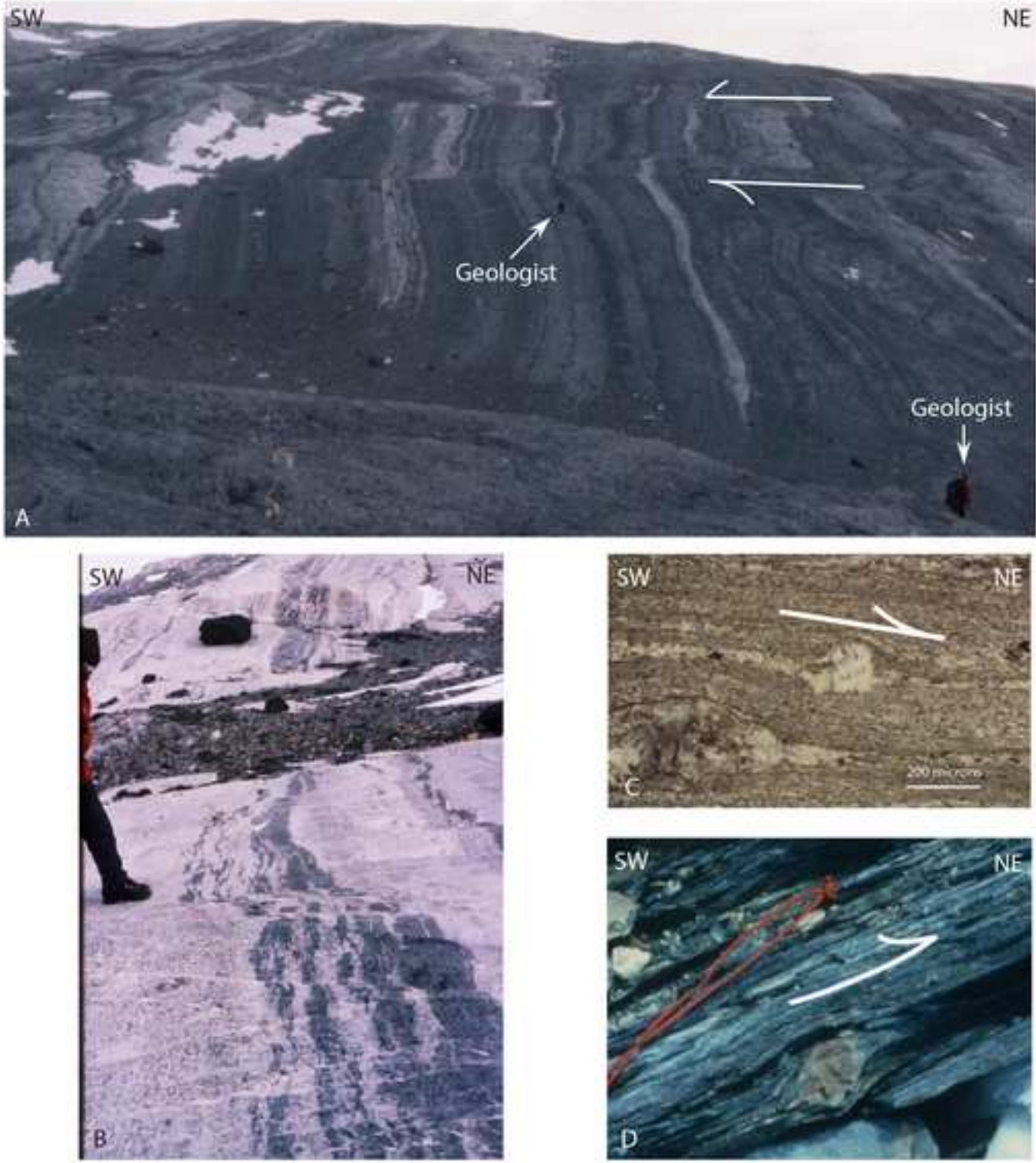

Figure 6: Strike-slip faults cutting the Cambrian Minaret Fm., Heritage Range (A, B; mylonitic marble) with top-to-the-ENE kinematic indicators in Minaret mylonites (C) and Heritage Group volcaniclastics. (D). 

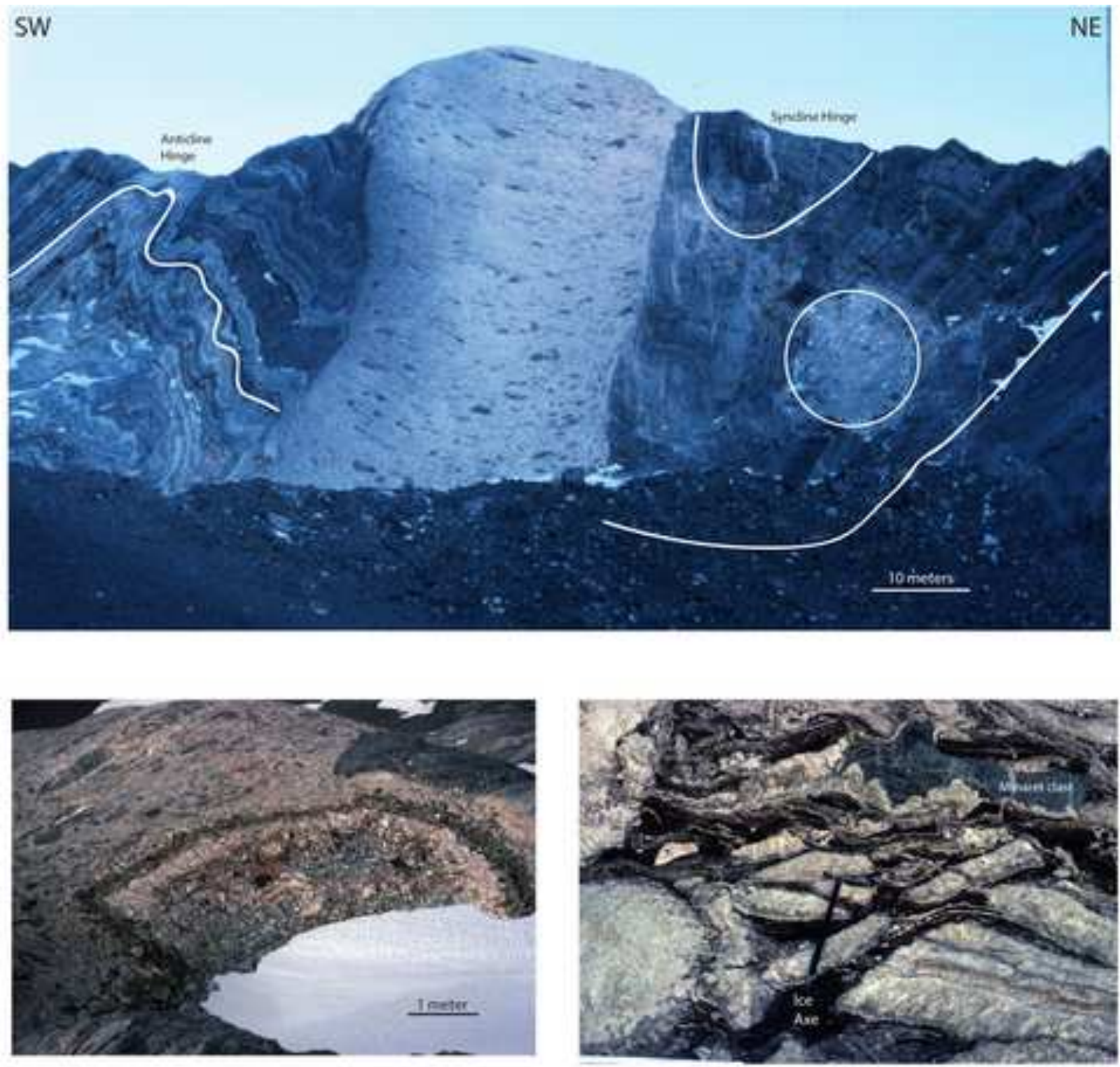

Figure 7: (A) The "type" carbonate breccia body ( 50 m high) in the southern Marble Hills of the Heritage Range. The vertical, cylindrical breccia body crosscuts an anticline-syncline pair and preserves a crude, subhorizontal layering with clasts of cleaved Minaret Fm. marble. A second, horizontal breccia cylinder is present to the right. Breccia bodies crosscut each other $(B)$ with younger breccias generally clastpoor and cleaved Minaret clasts are often serrated (C). 

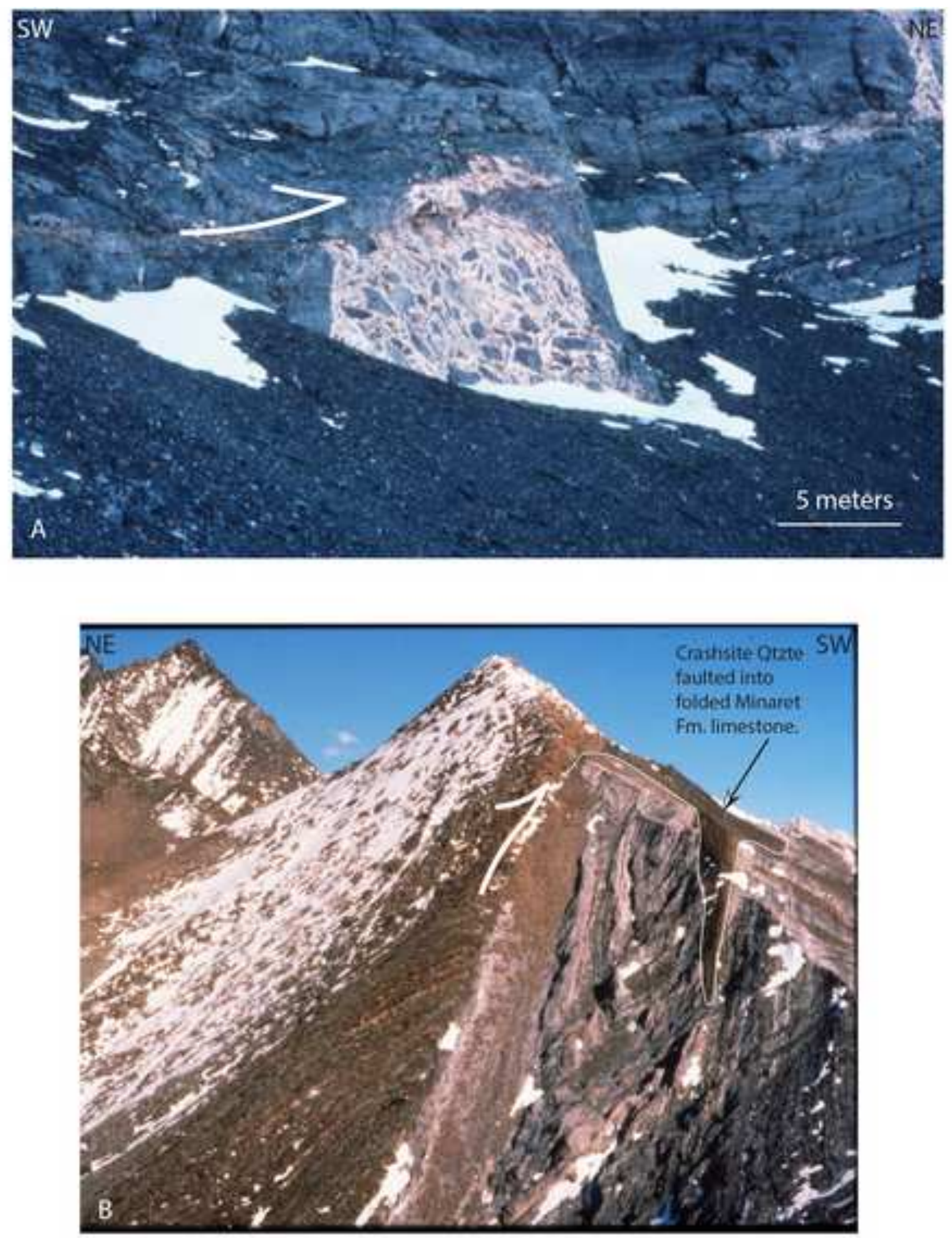

Figure 8: (A) Carbonate breccia body hosted in Cambrian Minaret $\mathrm{Fm}$. limestone truncated by a WSW-dipping thrust fault (top-to-the-northeast) and, (B) the Dolence fault (NW-SE strike) which juxtaposes folded Minaret Fm. limestones (that host breccia bodies) against Crashsite Group quartzites (see Fig. 2 for fault location). Sinistral motion kinematics are observed along the Dolence fault. 

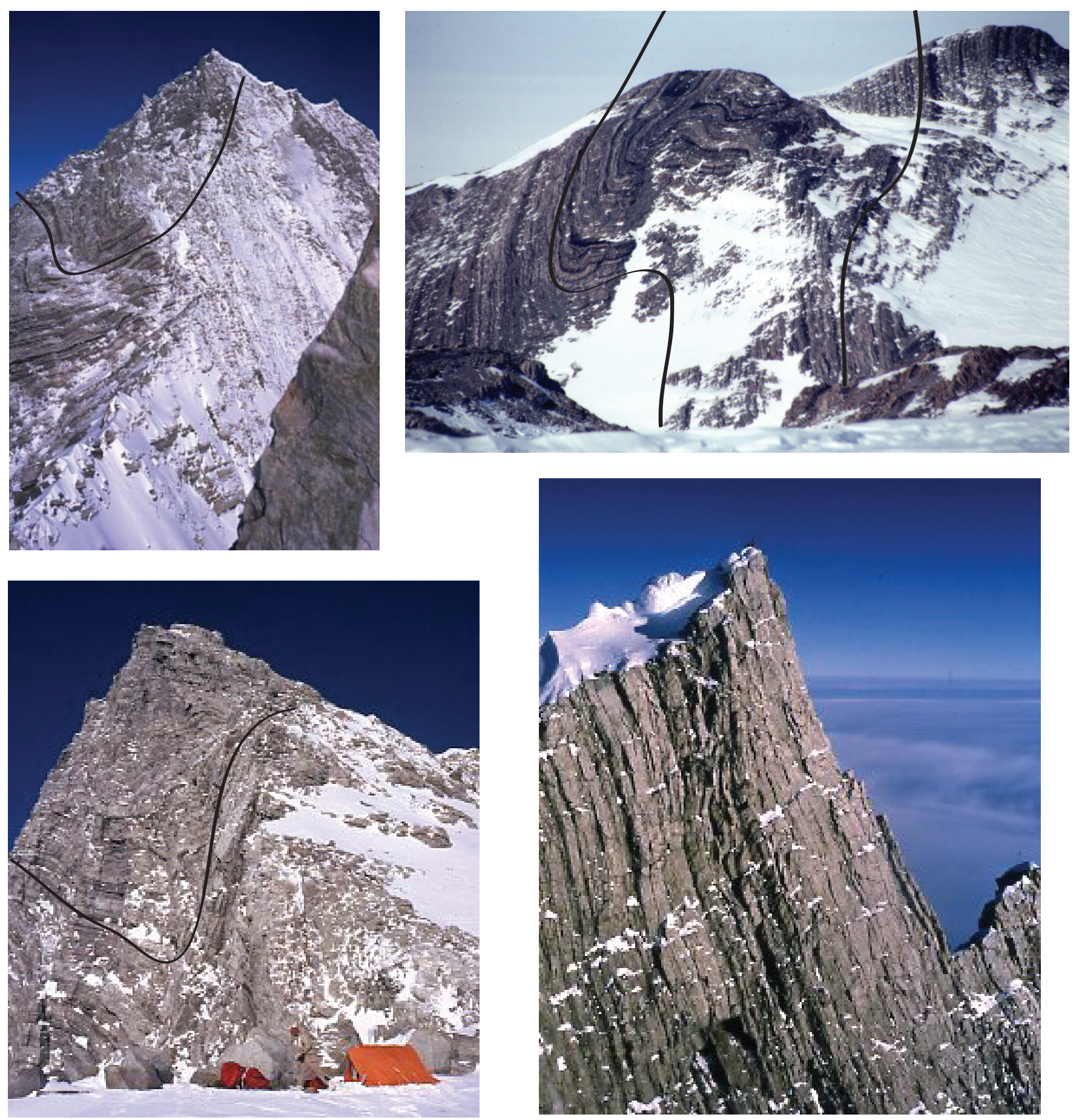

Figure 9: Fold complexities in the Crashsite Group (Mt. Liptak and Landmark Peak Fms.)at high elevations in the Sentinel Range. 


\section{Figure}

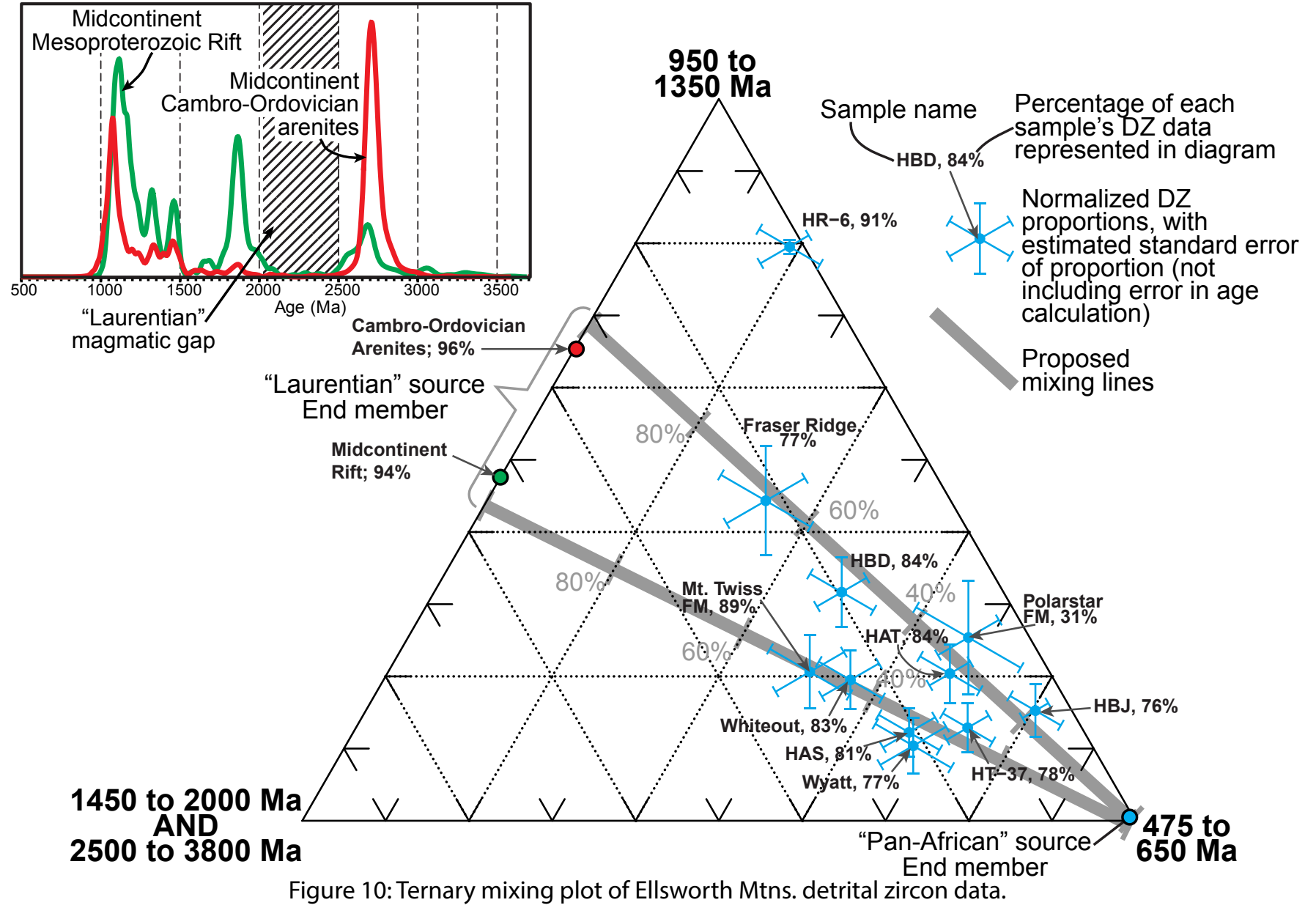



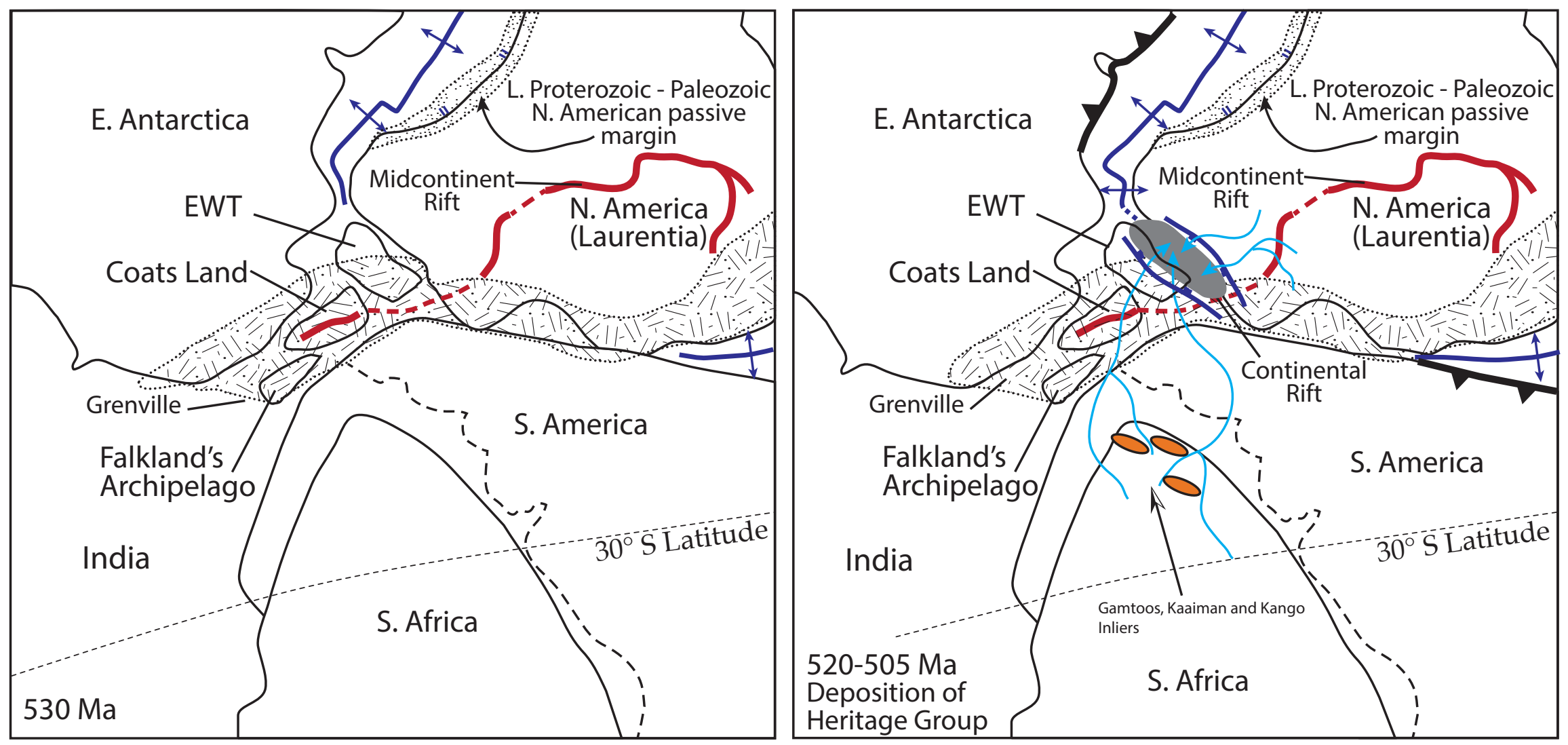

Figure 11: The northern margin of Rodinia representing the final convergence of Laurentia and the early Cambrian amalgamation of proto-Gondwana (see Dalziel, 1991, 1997; Curtis, 2001 and Leowy et al. 2011). Stippled areas are Grenville crust, including the EllsworthWhitmore terrane, which is beginning to rift to accomodate the deposition of $\sim 7000 \mathrm{~m}$ of midde-upper Cambrian volcaniclastic sediment (Webers et al. 1992; Curtis et al. 1999). 
$540 \mathrm{Ma}$

South
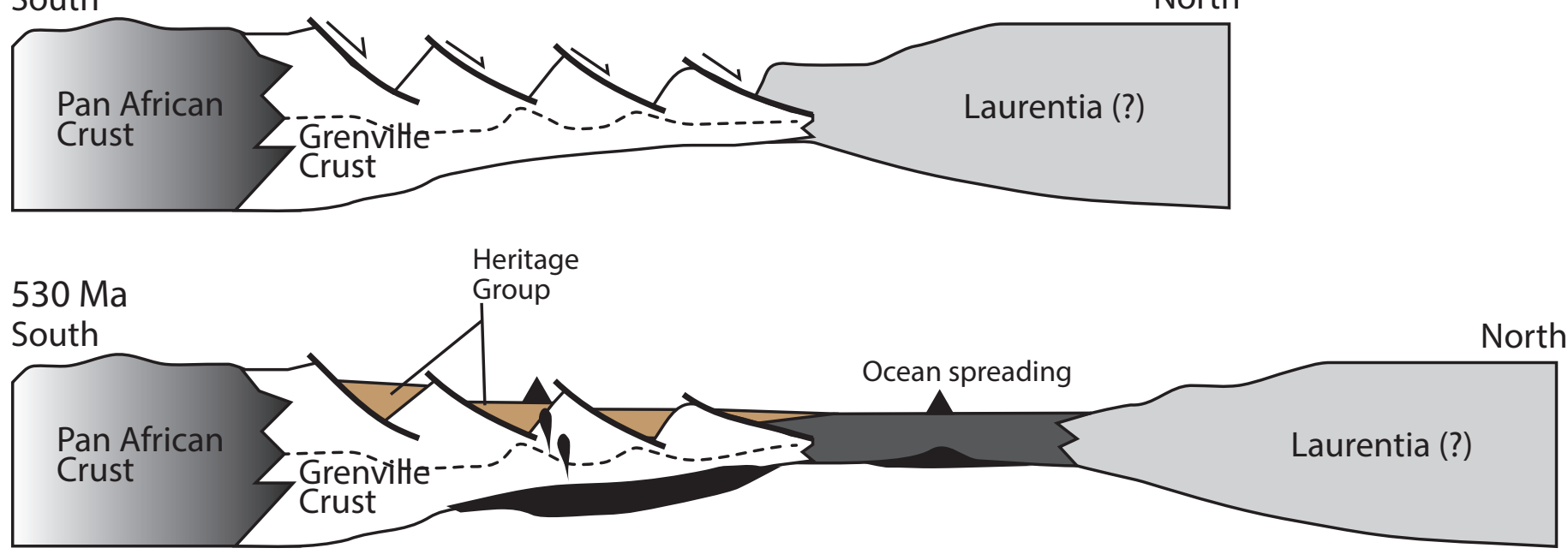

520-245 Ma

South

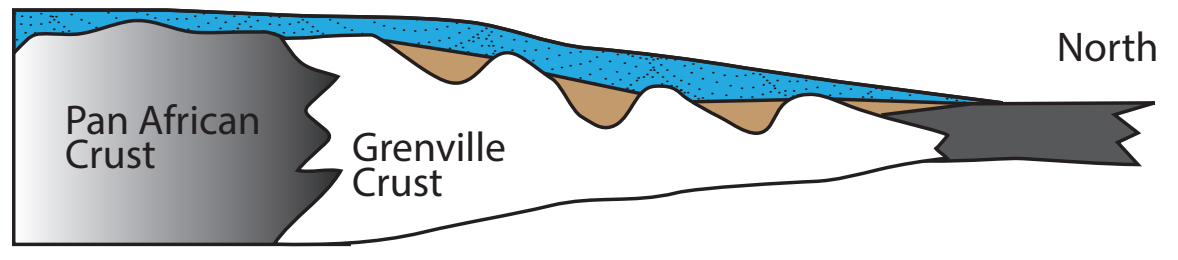

245-230 Ma

Shortening to the South,

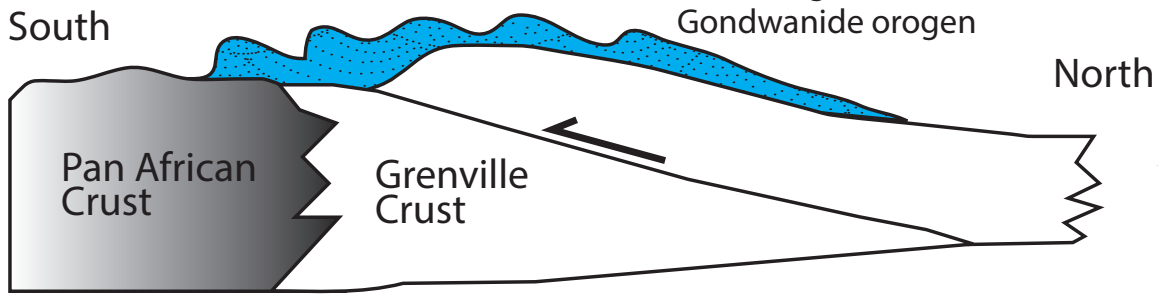

$170 \mathrm{Ma}$

East

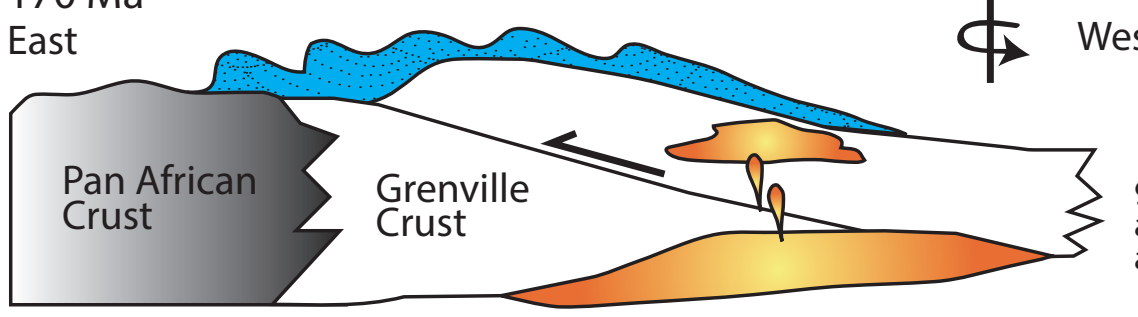

\$ west

Deposition of Cambrian-

Permian marine sediments
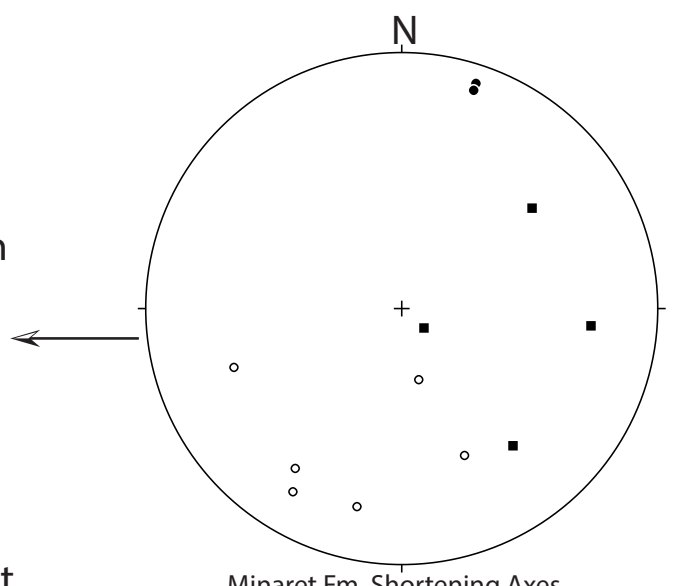

Minaret Fm. Shortening Axes (open circle: limestone, filled:vein; square: NEV strain overprint)

$90^{\circ}$ counterclockwise rotation and intrusion of Jurassic granites as Gondwana diverges

\section{Present Day}

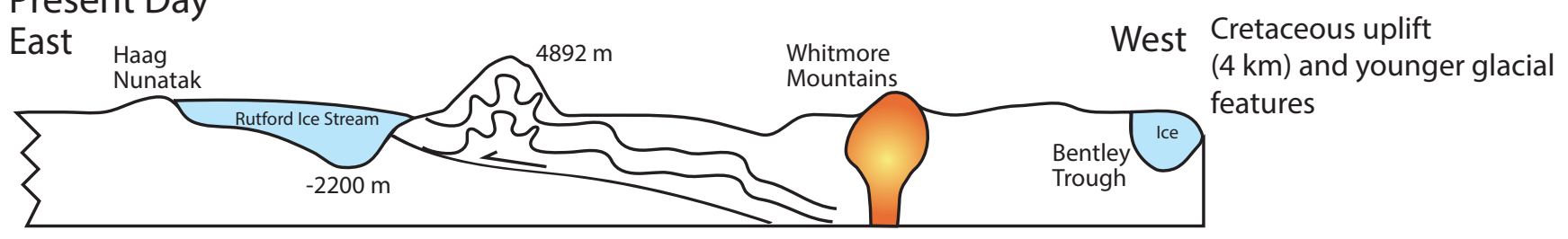

Figure 12: Schematic representation of the evolution of the Ellsworth-Whitmore terrane starting with rifting that led to the deposition of the Cambrian Heritage Group sediments, then the CambrianPermian Gondwana sedimentary sequence, all of which was deformed by the Gondwanide orogen. Intrusion of Jurassic granites followed as Gondwana diverged and the EWT rotated and uplifted to form the current high-standing mountain range. 


\section{Table 1: Ellsworth Mountains Detrital Zircon Data}

\begin{tabular}{|c|c|c|c|c|c|c|c|c|c|}
\hline $\begin{array}{c}\text { Sample } \\
11\end{array}$ & $\begin{array}{l}\text { Rock Unit } \\
\text { Polarstar Fm. } \\
\text { (Lower Argillite) }\end{array}$ & $\begin{array}{l}\text { Sample No. } \\
\text { OM-79-33 }\end{array}$ & $\begin{array}{l}\text { Locality } \\
\text { Match Ridge }\end{array}$ & $\begin{array}{c}\text { Position } \\
77^{\circ} 34^{\prime} 5.15 \mathrm{~S} \\
86^{\circ} 1^{\prime} 31.37 \mathrm{~W}\end{array}$ & $\begin{array}{c}\text { Elevation(m) } \\
2025\end{array}$ & $\begin{array}{c}\text { Zircons } \\
n=85\end{array}$ & $\begin{array}{c}\text { Youngest Zircon } \\
254 \mathrm{Ma}\end{array}$ & $\begin{array}{r}\text { Oldest Zircon } \\
3163 \mathrm{Ma}\end{array}$ & $\begin{array}{c}\text { Age } \\
\text { Permian }\end{array}$ \\
\hline 10 & $\begin{array}{l}\text { Whiteout Conglomerate } \\
\text { (Glacial Tillite) }\end{array}$ & OM-79-23H & Mt. Wyatt Earp & $\begin{array}{c}77^{\circ} 35^{\prime} 23.47 \mathrm{~S} \\
86^{\circ} 18^{\prime} 33.26 \mathrm{~W}\end{array}$ & 2057 & 81 & 519 & 3569 & Carboniferous \\
\hline 9 & $\begin{array}{l}\text { Crashsite Group\# } \\
\text { (Mt. Wyatt Earp Member) }\end{array}$ & R.6781.8A & Mt. Wyatt Earp & $\begin{array}{c}77^{\circ} 33^{\prime} 22.77 \mathrm{~S} \\
86^{\circ} 23^{\prime} 39.99 \mathrm{~W}\end{array}$ & 1893 & 44 & 379 & 2893 & Middle Devonian \\
\hline 8 & $\begin{array}{l}\text { Crashsite Group } \\
\text { (Mt. Liptak Fm.) }\end{array}$ & HAT & Vinson Massif & $\begin{array}{l}78^{\circ} 29.31 \mathrm{~S} \\
85^{\circ} 44.70^{\prime} \mathrm{W}\end{array}$ & 4014 & 80 & 484 & 3024 & Devonian \\
\hline 7 & $\begin{array}{l}\text { Crashsite Group } \\
\text { (Landmark Peak Fm.) }\end{array}$ & HAS & Vinson Massif & $\begin{array}{l}78^{\circ} 33.62^{\prime} \mathrm{S} \\
86^{\circ} 04.18^{\prime} \mathrm{W}\end{array}$ & 2135 & 83 & 484 & 3540 & Devonian \\
\hline 6 & $\begin{array}{l}\text { Crashsite Group } \\
\text { (Landmark Peak Fm.) }\end{array}$ & HBD & Vinson Massif & $\begin{array}{l}78^{\circ} 31.29^{\prime} \mathrm{S} \\
85^{\circ} 39.78^{\prime} \mathrm{W}\end{array}$ & 4887 & 76 & 511 & 3158 & Devonian \\
\hline 5 & $\begin{array}{l}\text { Crashsite Group } \\
\text { (Landmark Peak Fm.) }\end{array}$ & HR-6 & Bingham Peak & $\begin{array}{l}79^{\circ} 30^{\prime} 31.11 \mathrm{~S} \\
84^{\circ} 38^{\prime} 33.67 \mathrm{~W}\end{array}$ & 1394 & 83 & 505 & 1694 & Devonian \\
\hline 4 & $\begin{array}{l}\text { Crashsite Group } \\
\text { (Landmark Peak Fm.) }\end{array}$ & HBJ & E. Nimitz Glacier & $\begin{array}{l}78^{\circ} 42.59^{\prime} \mathrm{S} \\
85^{\circ} 42.54^{\prime} \mathrm{W}\end{array}$ & 1327 & 81 & 504 & 2032 & Devonian \\
\hline 3 & $\begin{array}{l}\text { Crashsite Group } \\
\text { (Mt. Twiss Member) }\end{array}$ & HR-37 & Landmark Pk. & $\begin{array}{c}79^{\circ} 7^{\prime} 16.02 \mathrm{~S} \\
85^{\circ} 25^{\prime} 28.24 \mathrm{~W}\end{array}$ & 1398 & 82 & 486 & 3452 & Devonian \\
\hline 2 & $\begin{array}{l}\text { Crashsite Group\# } \\
\text { (Mt. Twiss Member) }\end{array}$ & R.6758.4 & Mt. Rossman & $\begin{array}{l}79^{\circ} 46^{\prime} 47.12 \mathrm{~S} \\
82^{\circ} 44^{\prime} 25.24 \mathrm{~W}\end{array}$ & 1430 & 47 & 493 & 3141 & Cambro-Devonian \\
\hline 1 & $\begin{array}{l}\text { Heritage Group\# } \\
\text { (Fraser Ridge Fm.) }\end{array}$ & R.6208.2 & Buggisch Peak & $\begin{array}{c}79^{\circ} 49^{\prime} 11.69 \mathrm{~S} \\
83^{\circ} 57^{\prime} 19.55 \mathrm{~W}\end{array}$ & 1440 & 33 & 518 & 2668 & Upper Cambrian \\
\hline
\end{tabular}

(\#-Data from Flowerdew et al. (2007) 
Table 2: Calcite Twinning Strains, Heritage Range, Ellsworth Mountains, Antarctica

1
$2 V$
3
$3-N E V$
4
$4-N E V$
5
$5-N E V$
6
$6 V$
$6 V-N E V$
7
7

\begin{tabular}{lccc} 
Rock Unit & \multicolumn{4}{c}{ Calcite Type/Age Orientation } & Grains (n=) \\
Minaret Limestone & LS/Cambrian & $90^{\circ}, 32^{\circ} \mathrm{S}$ & 22 \\
Minaret Limestone & Vein/Cambrian & $21^{\circ}, 56^{\circ} \mathrm{E}$ & 24 \\
Minaret Limestone & LS/Cambrian & $280^{\circ}, 60^{\circ} \mathrm{S}$ & 76 \\
Minaret Limestone & LS/Cambrian & $285^{\circ}, 3^{\circ} \mathrm{S}$ & 19 \\
Minaret Limestone & LS/Cambrian & $290^{\circ}, 40^{\circ} \mathrm{S}$ & 71 \\
Minaret Limestone & LS/Cambrian & $290^{\circ}, 0^{\circ} \mathrm{S}$ & 20 \\
Minaret Limestone & LS/Cambrian & $290^{\circ}, 40^{\circ} \mathrm{S}$ & 35 \\
Minaret Limestone & LS/Cambrian & $290^{\circ}, 0^{\circ} \mathrm{S}$ & 14 \\
Minaret Limestone & LS/Cambrian & $285^{\circ}, 41^{\circ} \mathrm{S}$ & 27 \\
Minaret Limestone & Vein/Cambrian & $340^{\circ}, 90^{\circ}$ & 38 \\
Minaret Limestone & Vein/Cambrian & $340^{\circ}, 90^{\circ}$ & 15 \\
Minaret Limestone & LS/Cambrian & $290^{\circ}, 44^{\circ} \mathrm{S}$ & 37
\end{tabular}

$\begin{array}{ccc}\mathbf{1} & \mathbf{1}(\%) & \mathbf{2} \\ 211^{\circ}, 18^{\circ} & -11.2 & 301^{\circ}, 3^{\circ} \\ 18^{\circ}, 8^{\circ} & -11.1 & 118^{\circ}, 18^{\circ} \\ 167^{\circ}, 67^{\circ} & -12.6 & 283^{\circ}, 12^{\circ} \\ 52^{\circ}, 36^{\circ} & -3.1 & 318^{\circ}, 6^{\circ} \\ 251^{\circ}, 31^{\circ} & -12.5 & 168^{\circ}, 4^{\circ} \\ 95^{\circ}, 27^{\circ} & -6.9 & 274^{\circ}, 5^{\circ} \\ 214^{\circ}, 26^{\circ} & -3.3 & 312^{\circ}, 15^{\circ} \\ 141^{\circ}, 32^{\circ} & -8.3 & 237^{\circ}, 12^{\circ} \\ 193^{\circ}, 22^{\circ} & -13.4 & 274^{\circ}, 8^{\circ} \\ 110^{\circ}, 110^{\circ} & -4.3 & 277^{\circ}, 12^{\circ} \\ 131^{\circ}, 81^{\circ} & -4.1 & 243^{\circ}, 3^{\circ} \\ 157^{\circ}, 38^{\circ} & -6.3 & 79^{\circ}, 21^{\circ}\end{array}$

$2(\%)$
2.2
3.4
4.1
-0.2
3.8
-1.3
0.5
2.2
-1.8
-0.6
0.2
-1.3

3
$36^{\circ}, 88^{\circ}$
$308^{\circ}, 84^{\circ}$
$14^{\circ}, 11^{\circ}$
$219^{\circ}, 53^{\circ}$
$87^{\circ}, 14^{\circ}$
$183^{\circ}, 31^{\circ}$
$111^{\circ}, 52^{\circ}$
$357^{\circ}, 84^{\circ}$
$12^{\circ}, 87^{\circ}$
$169^{\circ}, 41^{\circ}$
$334^{\circ}, 8^{\circ}$
$312^{\circ}, 52^{\circ}$

$3(\%) \quad$ NEV (\%)

(bars) Fabric Interp.

LPS: Layer-parallel shortening; LNS: layer-normal shortening; VPS: vein-parallel shortening; VNS: vein-normal shortening.

$\begin{array}{ccc}9 & 20 & -357 \\ 7.7 & 12 & -423 \\ 8.5 & 25 & -326 \\ 3.4 & 100 & -421 \\ 8.7 & 28 & -372 \\ 8.2 & 100 & -457 \\ 2.8 & 41 & -412 \\ 6.1 & 100 & -532 \\ 15.2 & 18 & -488 \\ 5.9 & 40 & -531 \\ 3.9 & 100 & -502 \\ 7.6 & 7 & -458\end{array}$

Location

Soholt Peaks
Mt. Fordell Minaret Peak
Minaret Peak Mt. Fordell Mt. Fordell Mt. Fordell
Mt. Fordell
Minaret Peak Minaret Peak Minaret Peak
Mt. Fordell 